\title{
The Nutrient-Sensing Hexosamine Biosynthetic Pathway as the Hub of Cancer Metabolic Rewiring
}

\author{
Ferdinando Chiaradonna * (D), Francesca Ricciardiello and Roberta Palorini \\ Department of Biotechnology and Biosciences, University of Milano-Bicocca, Milan 20126, Italy; \\ francesca.ricciardiello@unimib.it (F.R.); roberta.palorini@unimib.it (R.P.) \\ * Corresponding: ferdinando.chiaradonna@unimib.it; Tel.: +39-0264483526
}

Received: 30 April 2018; Accepted: 31 May 2018; Published: 2 June 2018

\begin{abstract}
Alterations in glucose and glutamine utilizing pathways and in fatty acid metabolism are currently considered the most significant and prevalent metabolic changes observed in almost all types of tumors. Glucose, glutamine and fatty acids are the substrates for the hexosamine biosynthetic pathway (HBP). This metabolic pathway generates the "sensing molecule" UDP-N-Acetylglucosamine (UDP-GlcNAc). UDP-GlcNAc is the substrate for the enzymes involved in protein $\mathrm{N}$ - and $\mathrm{O}$-glycosylation, two important post-translational modifications (PTMs) identified in several proteins localized in the extracellular space, on the cell membrane and in the cytoplasm, nucleus and mitochondria. Since protein glycosylation controls several key aspects of cell physiology, aberrant protein glycosylation has been associated with different human diseases, including cancer. Here we review recent evidence indicating the tight association between the HBP flux and cell metabolism, with particular emphasis on the post-transcriptional and transcriptional mechanisms regulated by the HBP that may cause the metabolic rewiring observed in cancer. We describe the implications of both protein $\mathrm{O}$ - and $\mathrm{N}$-glycosylation in cancer cell metabolism and bioenergetics; focusing our attention on the effect of these PTMs on nutrient transport and on the transcriptional regulation and function of cancer-specific metabolic pathways.
\end{abstract}

Keywords: hexosamine biosynthesis pathway; UDP-GlcNAc; protein glycosylation; metabolism; bioenergetics; cancer

\section{Introduction}

Cancer cell growth is tightly correlated to an altered cellular metabolism. In particular, as Warburg noticed almost one century ago, cancer cells, even in the presence of oxygen, produce Adenosine Triphosphate (ATP) through glycolysis, a catabolic pathway predominantly considered to be of great importance under anaerobic conditions and that produces much less ATP than oxidative phosphorylation [1]. Nevertheless this alteration, known as the "Warburg effect", is nowadays considered a cancer hallmark, since it actively participates in the increasing requirements for macromolecular synthesis necessary to maintain rapid cancer proliferation. Indeed, the increased glucose consumption is used as carbon source for the de novo generation of nucleotides, lipids and proteins by its redirection into the multiple branching pathways that originate from glycolysis. It has been shown that increased glucose uptake allows a high rate of nucleotides and of reducing equivalents synthesis (NADPH) through the pentose phosphate pathway (PPP) [2,3], which are then used respectively to sustain DNA replication and mRNA transcription and most notably for lipid synthesis. In addition, glycolytic flux is also redirected into serine biosynthesis, since serine is a precursor of the nonessential amino acids glycine and cysteine. Glycine is in turn a precursor of purine nucleotide bases, and together with cysteine, of glutathione (GSH). Serine is also necessary for the production of sphingolipids and phospholipids and supplies carbon to the one-carbon pool, which is involved in folate metabolism, that participates in thymidine synthesis and the 
regeneration of methionine from homocysteine and thus facilitates the generation of $S$-adenosylmethionine (SAM), the methyl donor for both DNA and histone methylation. On the other hand, the pyruvate produced by glycolysis is converted to lactate, and this step is essential for the regeneration of $\mathrm{NAD}^{+}$in the cytosol to sustain the high glycolytic rate observed in tumors [2,3]. Therefore, this metabolic switch from oxidative respiration to glycolysis is indispensable, providing cancer cells with ATP and most of the anabolic intermediates required to sustain high rates of cellular proliferation, in terms of nucleotide synthesis, reducing power (NADPH, NADH) and building blocks for lipid and amino acid biosynthesis.

Another branch of glycolysis, in which the glucose is directly diverted, is the hexosamine biosynthesis pathway (HBP) [4,5]. The HBP is characterized by six enzymatic steps, of which two are shared with glycolysis (Figure 1).

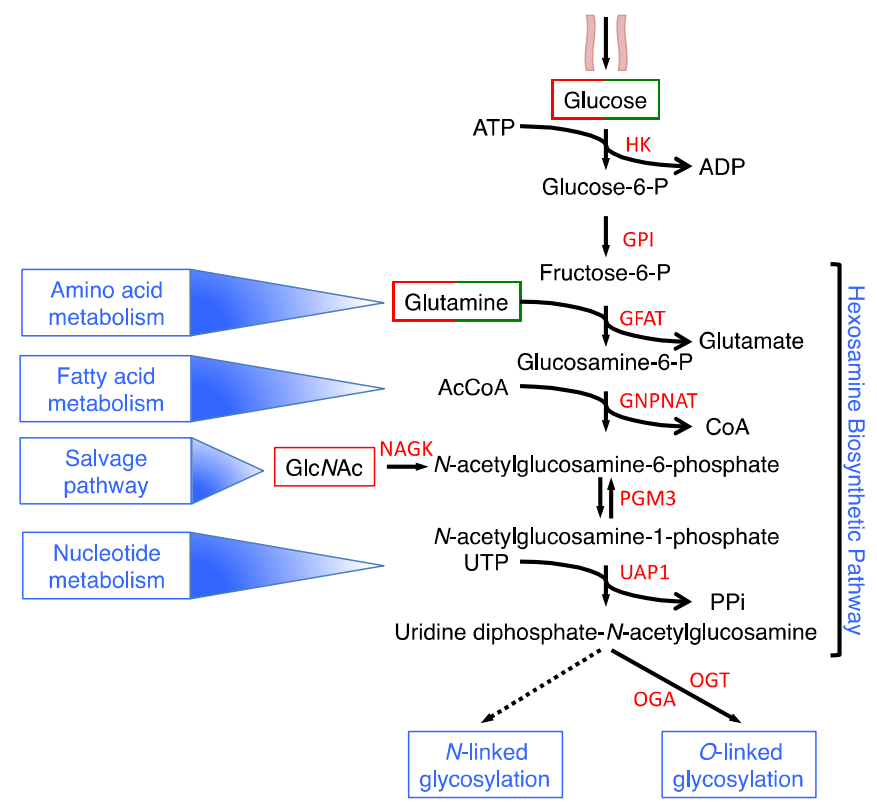

Figure 1. Schematic representation of the hexosamine biosynthesis pathway. HBP enzymes are depicted in red, metabolites in black, cellular processes in light blue. The green/red boxes indicate the metabolites whose change induces UDP-GlcNAc decrease (green) or increase (red).

In fact, hexokinase (HK) phosphorylates glucose to produce glucose-6-phosphate, which is then converted into fructose-6-phospate by phosphoglucose isomerase (GPI). Fructose-6-phospate and glutamine are converted into glucosamine-6-phosphate (GlcN-6P) and glutamate (Glu) by the first HBP rate-limiting enzyme glutamine: fructose-6-phosphate transaminase (GFAT). The next enzyme, glucosamine-phosphate $N$-acetyltransferase (GNPNAT) converts the GlcN-6P and the Acetyl-Coenzyme A (Ac-CoA) into N-acetylglucosamine-6-phosphate (GlcNAc-6P) and CoA. Then, GlcNAc-6P is isomerized in GlcNAc-1P by the GlcNAc phosphomutase (PGM3/AGM1) and finally, the UDP- $N$-acetylglucosamine pyrophosphorylase (UAP1) converts UTP and GlcNAc-1P into UDP- $N$-acetylglucosamine (UDP-GlcNAc) and pyrophosphate (PPi). UDP-GlcNAc is the substrate for $\mathrm{O}$ - and $\mathrm{N}$-glycosylations, being a component of simple and complex branched $\mathrm{O}$ - and $\mathrm{N}$-glycans, whose attachment to the proteins leads to the formation of complex glycoproteins and proteoglycans named glycoconjugates. These are mainly expressed on the cell surface, where they form a dense array, the so-called glycocalyx, or are secreted into the extracellular space where they are incorporated into the extracellular matrix [6]. UDP-GlcNAc is also the substrate for a less complex type of glycoconjugate, the protein O-GlcNAcylation [7], which has been found on many cytoplasmic, nuclear and mitochondrial proteins, and is considered a dynamic PTM, analogous to phosphorylation, regulating many cellular functions [8]. Glycan structures and types depend on the gene expression, 
on the activities of several enzymes, i.e., the enzymes present in the Golgi, and on the availability of the main donor substrate, UDP-GlcNAc.

Although the glucose flux is possibly different in the various cell types, some reports have indicated that around $1-3 \%$ of total cellular glucose is channeled into the HBP [9]. Several data underline the role of the HBP as an integrator and sensor of the main cellular metabolic molecules, namely carbohydrates (glucose), amino acids (glutamine), lipids (Acetyl-CoA, Ac-CoA) and nucleotides (uridine), in order to synthesize the final product of the pathway UDP-GlcNAc. This metabolite is not directly involved in any anabolic process, since it fundamentally serves, as previously described, as a building block for protein- and lipid-glycoconjugate biosynthesis $[5-7,10]$. In this context, the ability of HBP to integrate and sense the main intracellular metabolites strongly supports the important role of this pathway and of its final product UDP-GlcNAc in the regulation of cell metabolism both in physiological conditions and in the metabolic changes observed in several human diseases, such as cancer. Therefore, in this review we explore the connection between the HBP and cell metabolism with a particular emphasis on the association between HBP and the metabolic rewiring observed in cancer cells.

\section{HBP Flux Is Modulated in a Nutrient-Dependent Fashion}

Several authors have shown that changes in intracellular nutrient concentration modulate the intracellular UDP-GlcNAc amount and HBP flux (Figure 1). In this regard it has been shown that increased glucose availability in isolated adipocytes, pretreated with insulin to enhance their glucose transport, induces a rapid increase of UDP-GlcNAc, since this increase can be seen as early as $5 \mathrm{~min}$ after the addition of glucose and remains almost stable until $4 \mathrm{~h} \mathrm{[11].} \mathrm{Similar} \mathrm{results} \mathrm{have} \mathrm{been}$ obtained in different cell models, such as mesangial cells [12], colon cancer cells [13] and human cervix cancer cells [14]. Conversely, $24 \mathrm{~h}$ of glucose depletion in different types of hematopoietic cells induces an early reduction of UDP-GlcNAc [15]. Comparable results have been also obtained in K-Ras-transformed mouse fibroblasts [16], human hepatocellular carcinoma cells [17], breast cancer cells and pancreatic cancer cells $[18,19]$. Notably, it has also been shown that glucose reduction may also enhance the HBP flux, in particular protein O-GlcNAcylation, by increasing the mRNA and the protein expression of some HBP enzymes. In fact, some authors have reported the capacity of different types of cells to activate compensative mechanisms to sustain HBP flux and survival under moderate glucose depletion [19-22], underlining the strong glucose sensing capacity of HBP. These latter authors did not evaluate the HBP flux in function of the UDP-GlcNAc amount generated upon glucose reduction, but measured intracellular protein $O$-GlcNAcylation, therefore it is not possible to exclude different mechanisms, such as OGT protein activity increase or stability.

Changes in glutamine availability in cell culture and tissues, as above described for glucose, also lead to a modulation of the UDP-GlcNAc amount and HBP flux. In particular, in human cervix cancer cells and murine embryonic fibroblasts, the progressive glutamine increase from $0 \mathrm{mM}$ to $8 \mathrm{mM}$ causes a parallel increase in UDP-GlcNAc (2.5-fold increase) or protein O-GlcNAcylation (almost 2-fold), respectively [14,23]. This glutamine-dependent effect on intracellular UDP-GlcNAc concentration has also been observed in immune activated $\mathrm{T}$ cells upon addition of $2 \mathrm{mM}$ glutamine, as compared to a complete depletion of glutamine from the medium [24]. The enhancement of UDP-GlcNAc has also been observed in a more complex model, such as rat heart. Indeed, isolated rat hearts pre-treated with $2.5 \mathrm{mM}$ glutamine show an ischemic protection associated with a significant increase in the levels of UDP-GlcNAc and protein $O$-GlcNAcylation [25]. As previously described for glucose, for glutamine availability the effect on protein O-GlcNAcylation has also been well described. In fact, either in several diffuse large B-cell lymphoma cell lines or murine embryonic fibroblasts, an increased protein O-GlcNAcylation following the glutamine addition to cell culture has been observed [23,26], supporting the ability of HBP to adapt its flux in function of the intracellular glutamine availability.

UDP-GlcNAc can also be generated through the salvage pathway, which requires the phosphorylation of GlcNAc by GlcNAc kinase (NAGK). GlcNAc, the major component of complex carbohydrates found in glycoproteins, glycolipids, and proteoglycans, is thus recycled from the 
lysosomal degradation of these oligosaccharides. Some evidence suggests that this pathway complements the de novo synthesis of UDP-GlcNAc [27,28]. The positive effect of the GlcNAc supplementation on the intracellular UDP-GlcNAc level has been observed in different cell and organism models. In mouse hepatocyte cells (AML12 cells), the addition of increasing concentrations of GlcNAc (between 0 and $40 \mathrm{mM}$ ) leads to a six-fold increase in UDP-GlcNAc [10]; similarly, in Jurkat $\mathrm{T}$ cells the supplementation of $10 \mathrm{mM}$ GlcNAc for $72 \mathrm{~h}$ increases the UDP-GlcNAc almost six-fold [29]. This effect has been observed also in young male C57BL/ 6 mice, since oral GlcNAc-supplementation also leads to an increase of intracellular UDP-GlcNAc [10].

The HBP sensing for fatty acids has been poorly described. However, the few reports showed that in rat models the enhancement of free fatty acids by direct infusion induces an increase in UDP-GlcNAc in their skeletal muscle [30] and that palmitate-stimulated myotubes respond with a 1.3-fold increase of UDP-GlcNAc. These latter authors show also that UDP-GlcNAc is enhanced by saturated C16 and C18 fatty acids, but not by unsaturated C16 and C18 fatty acids [31]. Even though the molecular mechanism of such an effect has not been well explained, these findings suggest a sensing role of HBP also for the intracellular fatty acid availability.

In this contest, the enhanced uptake and utilization of glucose and glutamine, as well as the increased fatty acid uptake and biosynthesis, at least in the specific context and tumor stage [32], may provide an explanation for the enhanced HBP flux observed in tumors [33-36].

On the other hand, the increase of HBP flux, UDP-GlcNAc levels and protein glycosylation observed in cancer is also due to changes in the expression of the HBP enzymes. An important role for the sensing mechanism of the HBP, especially regarding glucose availability, must be assigned to the enzyme catalyzing the first step of the HBP, GFAT. It has been shown that an increased intracellular amount of glucose or of UDP-GlcNAc may cause an enhancement or a reduction of GFAT activity, respectively [13,37-39]. Its important role in HBP flux has also been shown either by its chemical inhibition through the use of the glutamine analogues Azaserine and 6-diazo-5-oxo-L-norleucine (DON) [15] or by gene silencing [13]. Both approaches cause a significant depletion of the intracellular UDP-GlcNAc pool, confirming its relevant role in HBP flux. GFAT is tightly controlled at the transcriptional level. In fact, diverse stimuli, among which some involved in cancer onset and growth, have been associated with GFAT gene expression regulation. For instance, GFAT mRNA increased expression has been observed upon EGF stimulation in breast cancer cells [40], upon androgen treatment in prostate cancer cells [41] and upon hypoxia in pancreatic cancer cells [42]. Conversely, oncogenic K-Ras inactivation in pancreatic cancer cells causes a significant down-regulation of GFAT mRNA and protein levels [43]. GFAT activity is controlled also by means of phosphorylation. Indeed, protein kinase A (PKA) and AMP-activated protein kinase (AMPK), as described below, are able to modulate its activity positively and negatively, respectively.

Altogether these findings indicate that HBP is able to adjust the flux in function of the glucose, glutamine and fatty acid availability and that this adjustment leads to a change of the level of the "sensor" molecule UDP-GlcNAc. They also indicate that these nutrients might be substituted by GlcNAc, through the action of NAGK, involved in the salvage pathway. In addition, they indicate an important role of the GFAT enzyme in HBP flux regulation. Finally, they indicate an association between HBP flux enhancement and cancer-specific metabolic changes.

\section{Nutrient Transporters Function, Localization and Stability Is Regulated by HBP through the Control of Their Glycosylation Levels}

As previously described, the main function of the HBP pathway is to generate the building blocks for glycoconjugate biosynthesis. Glycosylation is an important protein PTM occurring in the cytoplasm, the endoplasmic reticulum and the Golgi apparatus. $\mathrm{N}$ - and $\mathrm{O}$-linked glycosylation, the major forms of eukaryotic glycosylation, have been identified in almost $50 \%$ of the cellular proteins. Abnormalities in protein glycosylation are common in several diseases, including cancer [44], and they can be a hallmark 
of carcinogenesis and cancer metastasis, since glycoconjugates play different roles in several steps of tumor progression, regulating tumor proliferation, invasion, metastasis and angiogenesis $[4,33,44]$.

Among the different proteins involved in carcinogenesis and, in particular, in the metabolic rewiring observed in cancer, nutrient transporters carry out an important role. Accordingly, several oncogenic signaling pathways are strictly linked to the increased expression of the nutrient transporters $[45,46]$. Among the different mechanisms associated with nutrient transporter activity, more recently, their glycosylation status has been more investigated.

Glucose is an important nutrient for the proliferating cells and several glucose transporters are associated with cancerogenesis, such as the glucose transporter 1, 3 and 4 (GLUT1, GLUT3, GLUT4) and the sodium-dependent glucose transporter 1 (SGLT1) [47]. Previous studies showed that GLUT1 N-glycosylation is important for its transport activity [48], its membrane targeting and its stability [49]. K-Ras-transformed fibroblasts show an increased GLUT1 N-glycosylation associated with an enhancement of glucose uptake [50]. The importance of such $\mathrm{N}$-glycosylation in different transformed cells has been shown using specific mutants of the glycosylation sites [49] and by using the $\mathrm{N}$-glycosylation inhibitors tunycamicin and swainsonine [50-52]: both approaches supported the role of GLUT1 glycosylation for its targeting, stability as well as affinity for glucose. Further support for an association between GLUT1 glycosylation and its function has been gained in respiration-deficient cells, in which the enhanced glucose transport by GLUT1 is dependent on its glycosylation status [53]. Other glucose transporters involved in cancerogenesis, i.e., SLGT1, GLUT4 and GLUT3, have also been found to be glycosylated, but only a few reports have specifically addressed the role of glycosylation in their function [54]. Nevertheless, reduction of SLGT1 N-glycosylation lowers its affinity for the substrate [55] and the reduction of GLUT4 $N$-glycosylation reduces transporter stability [56]. Altogether these findings support a role of glycosylation in the function of this class of nutrient transporters (Figure 2). However additional work is needed to address the direct relation between the enhanced flux in HBP, glucose transporter activity, stability and localization specifically in cancer.
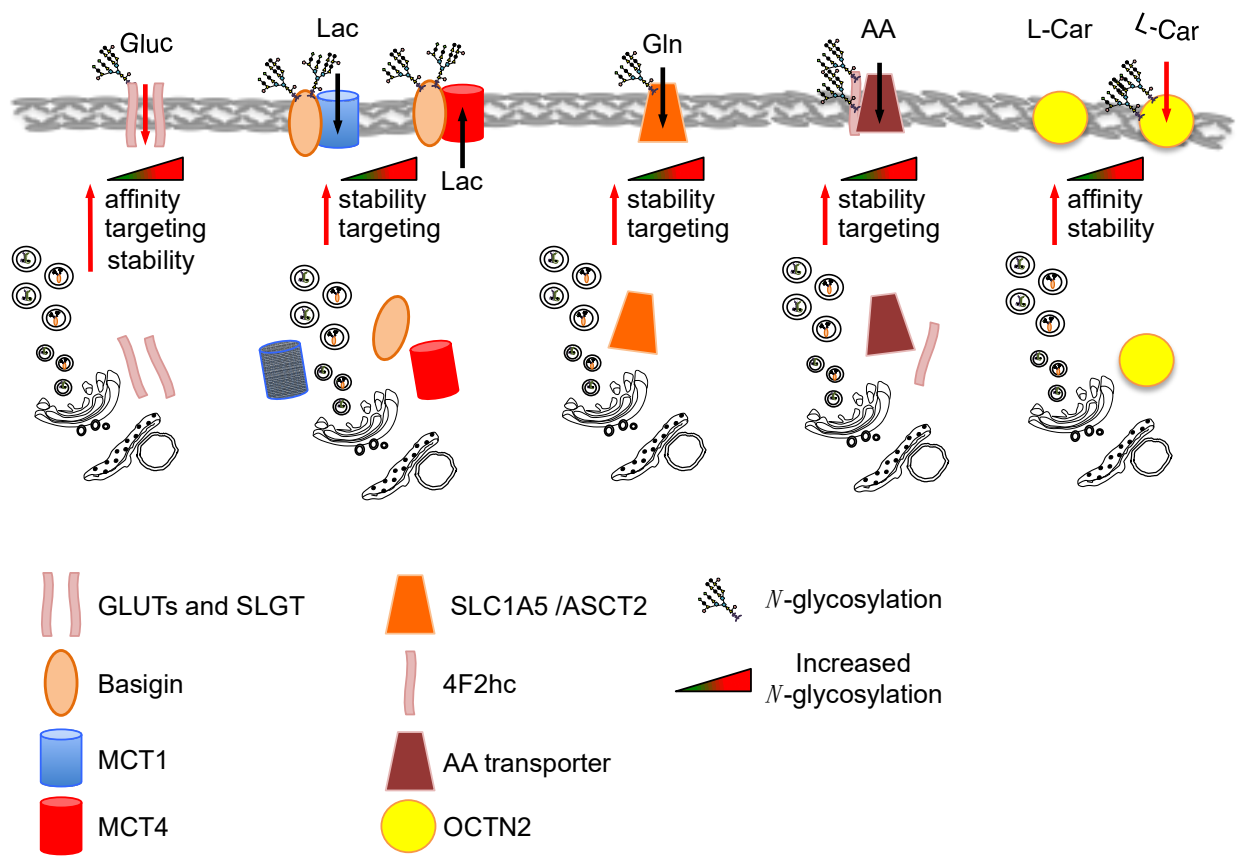

Figure 2. Schematic representation of the nutrient transporters discussed in the text. The arrows in the transporters indicate the direction of the flux. The red arrows indicate the increased nutrient transport and/or transporter affinity/targeting/stability. The single or double symbol of $N$-glycosylation indicates low or high glycosylated protein, respectively. The cartoon representing endoplasmic reticulum and Golgi indicates stability and targeting. Gluc: glucose; Lac: lactate; Gln: glutamine; AA: amino acid; L-Car: L-carnitine. 
Another important class of nutrient transporters often overexpressed in cancer is monocarboxylate transporters (MCTs), which catalyze the proton-linked transport of monocarboxylates such as L-lactate, pyruvate and the ketone bodies [57]. Importantly, the MCT family does not appear to be glycosylated and its translocation seems to be dependent on the glycosylation of Basigin (CD147), a tumor-associated antigen highly expressed on the cell surface of various tumors [58] that is involved in the correct translocation of the transporters to the plasma membrane (Figure 2). Recently it has been shown that the mammalian target of rapamycin complex 2 (mTORC2), a protein kinase complex that plays a key role in nutrient sensing and cellular metabolism, is required to modulate the HBP via the regulation of GFAT1 expression. In fact, the inactivation of mTORC2 leads to profound defects in the metabolic pathways in association with the appearance of some under-glycosylated proteins, including CD147, suggesting a direct correlation between HBP, CD147 glycosylation and the metabolic changes observed in these mTORC2-inactiveted cells [59].

Another important metabolic change observed in tumors is the increased uptake and utilization of glutamine $[60,61]$. Accordingly, oncogenic transformation frequently up-regulates the expression of transporters such as the solute carrier family 1 member 5 (SLC1A5/ASCT2), a Na ${ }^{+}$-coupled amino acid transporter whose main function in cancer cells is glutamine uptake (Figure 2). Different structural studies have shown the presence of $\mathrm{N}$-glycosylation sites in this transporter. In this regard, by using a mutagenic approach in the putative glycosylation sites, it has been recently suggested that the $\mathrm{N}$-glycosylation of ASCT2 favors its delivery to the membrane and slows down its degradation. No effect on its activity has been observed [62]. The relation between HBP pathway and ASCT2 $\mathrm{N}$-glycosylation may be argued from the results obtained by Polet et al. [63] in leukemia cells upon glucose depletion or tunicamycin treatment. Both treatments caused a significant de-glycosylation of ASCT2 in association with a significant mRNA up-regulation of other glutamine transporters (namely ASCT2, SLC7A8, SLC38A1, SLC38A5, SLC7A5), including SLC7A5/LAT1, which does not need glycosylation for its membrane localization, and thus appeared the most significant. Altogether these findings suggest that HBP flux may control glutamine and amino acid transporter membrane localization and stability.

Several other amino acid transporters have been found to be overexpressed in tumors, among which a relevant role in tumorigenesis has been indicated for SLC7A11 (xCT), LAT1, and the amino acid transporter dimerization partner 4F2 heavy chain antigen (SLC3A2/4F2hc). The 4F2hc is highly expressed in tumor cells and its expression correlates with tumor development, progression and metastatic potential [64]. In particular, in gastric cancer, in which it is overexpressed, it is only present in a highly glycosylated form as compared to normal tissue, in fact tunicamycin treatment of several gastric cancer cells leads to a reduction of its molecular weight from around $150 \mathrm{kDa}$ to $60 \mathrm{kDa}$, the latter observed only in normal cells [65]. Only one study has addressed the role of the 4F2hc protein $\mathrm{N}$-glycosylation. In fact, site-specific mutations of the three putative $\mathrm{N}$-glycosylation sites causes protein half-life reduction [66]. A multiproteic CD147-4F2hc complex has been specifically identified on the proliferating cancer cell surface. This complex seems to play a critical role in energy metabolism, probably due to its capacity to coordinate either the transport of lactate (via MCT1 and MCT4) or amino acids (via LAT1 and xCT) [67,68].

Another transporter involved in the proliferation associated with specific metabolic changes of ER-positive breast cancer cells is the solute carrier family 22 member 5 (SLC22A5), which encodes an organic cation/carnitine transporter (also called OCTN2) [69,70]. This transporter has a high affinity for the carnitine directly involved in lipid metabolism and cellular bioenergetics [71]. OCTN2 N-glycosylation has an important role in its turnover and affinity for the substrate [72] (Figure 2).

Worthy of mention is also the effect of glycosylation on the different proteins involved either in lysosome function and/or autophagy. In fact, as reviewed elsewhere [73,74], the glycosylation of specific proteins, such as autophagy-related protein 9 (ATG9) ( $N$-glycosylated) [75] and lysosome-associated membrane protein 1 and 2 (LAMP-1 and 2) ( $\mathrm{O}$ - and $\mathrm{N}$-glycosylated) [76,77], is directly involved either in 
the positive or negative regulation of autophagic flux, a process involved in both cancer suppression and promotion, depending on the cell context.

\section{O-GlcNAcylation and Cancer}

O-GlcNAcylation corresponds to the attachment of UDP-GlcNAc to specific Ser/Thr residues of target proteins. The O-GlcNAcylation is catalyzed by $\mathrm{O}$-GlcNAc transferase (OGT). Conversely, the de-OGlcNAcylation is catalyzed by $\beta-N$-acetylglucosaminidase (OGA) [7]. Protein O-GlcNAcylation influences either the activity or the stability of the target proteins and is involved in a complex interplay with phosphorylation, since these two PTMs can occur at the same or adjacent amino acidic residues, as well as at distant sites in the same protein [78]. As reviewed by Fardini et al., O-glycosylated proteins can be divided according to their function. In particular they can be grouped in proteins involved in the transcription and translation regulation $(\approx 26 \%)$, in the cellular structure formation $(\approx 14 \%)$, in the control of the cellular metabolism $(\approx 13 \%)$, in the response to cellular stress conditions $(\approx 11 \%)$, in the processes of protein folding and processing $(\approx 7 \%)$, in cellular signaling $(\approx 8 \%)$ and in cell cycle progression $(\approx 2 \%)[79]$. Considering the high number of cellular processes that are regulated by protein $O$-GlcNAcylation, an alteration of its level leads to profound changes in the cells.

The enhancement of protein O-GlcNAcylation has been observed in many tumors as a consequence of both an increase of the HBP flux, as described previously, and of the changes in the expression of the O-GlcNAcylation cycling enzymes, OGT and OGA (for review see [79-81]). Specifically, the increase of the OGT has been observed in different types of tumor, such as breast [82-86], colon [87,88], liver [89], endometrial [90], cervical [91], lung [87], prostate [41,92] and pancreatic [93] cancer, and it has often been associated with a parallel decrease of either the OGA levels or the OGA/OGT ratio [86,89,92]. Interestingly, such a change in the $O$-GlcNAcylation enzymes has been also correlated to the aggressiveness and the tumor grade $[86,90]$. Further, the increase in protein $O$-GlcNAcylation has been associated with the expression of an oncogenic K-ras protein [43], the activation of the MAPK/ERK signaling [94], the c-Myc amplification [95] and the tumor hypoxia [42]. Because these events, which influence either the HBP flux or OGT expression, are present in several types of tumors, protein hyper-O-GlcNAcylation, as described elsewhere [79,81], is more and more considered to be an important driver for tumor onset, progression, malignancy and appearance of cancer hallmarks.

Therefore, we will next describe its role in controlling cell metabolism and in particular the link with the metabolic rewiring observed in cancer cells.

\section{O-GlcNAcylation of Metabolic Enzymes and Mitochondrial Proteins}

Several authors have described the O-GlcNAcylation of different metabolic enzymes. In some cases the regulatory function of such a PTM in terms of protein localization, activity or function has also been clarified. Almost all glycolytic enzymes have been found to be O-GlcNAcylated [83,96-98] (Figure 3A) and for phosphofructokinase1 (PFK1), glyceraldheyde-3-phosphate (GAPDH) and pyruvate kinase M2 (PKM2) the effect of this PTM has also been investigated. 

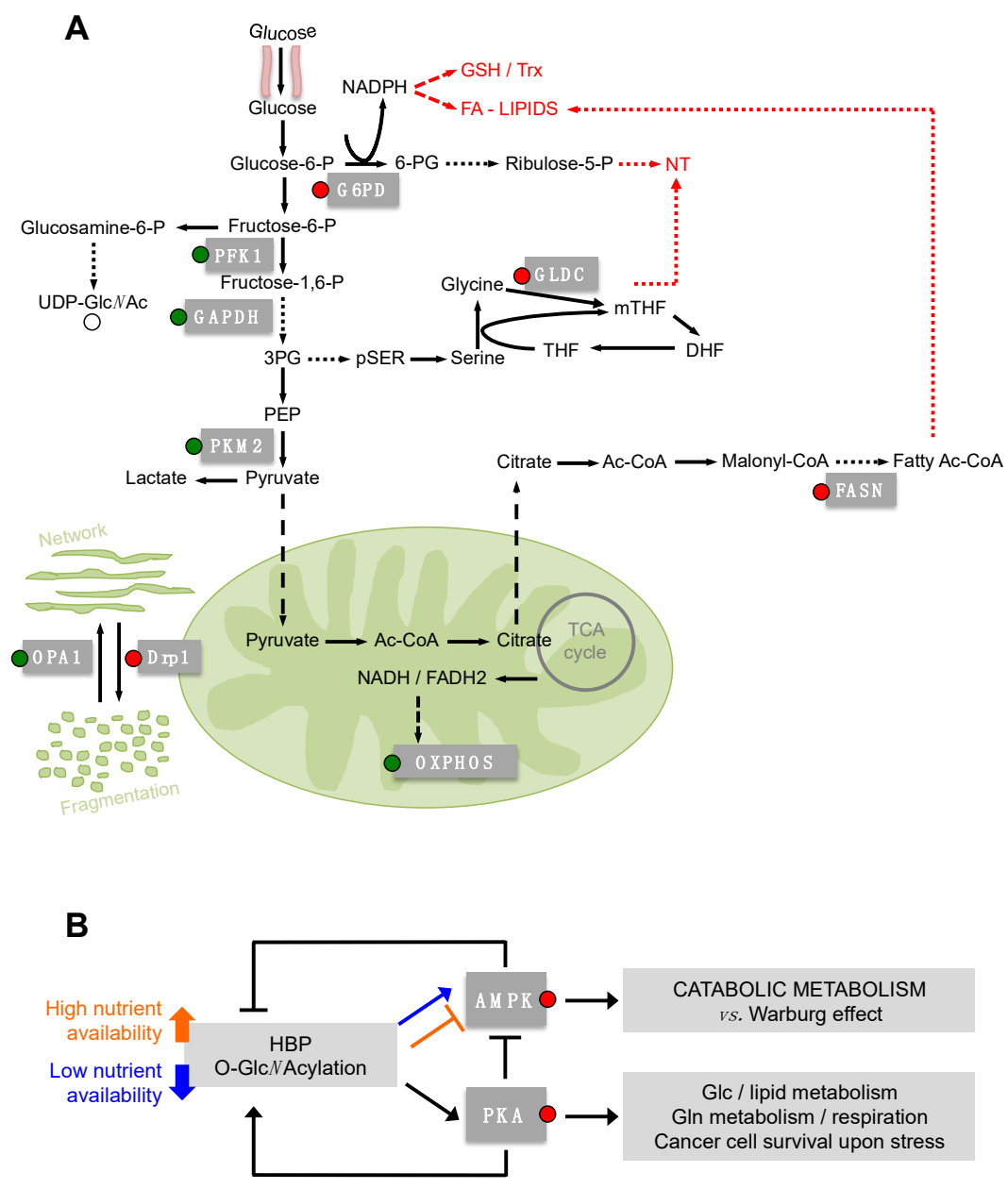

Figure 3. HBP modulates cancer metabolism through the O-GlcNAcylation of metabolic enzymes, signaling proteins and mitochondrial proteins. (A) In the image, the main metabolic pathways exploited by cancer cells for anabolism and bioenergetics are represented. The O-GlcNAcylated proteins (mainly the metabolic enzymes) are indicated in the grey boxes if the effect of the glycosylation has been demonstrated. The circle on the box, representing the O-GlcNAcylation, is red when the protein function is activated by glycosylation and green when it is inhibited. (B) The reciprocal regulation of AMPK and PKA and the HBP is schematically represented as discussed in the main text. 6-PG, 6-phosphogluconate; 3-PG, 3-phosphoglycerate; PEP, phosphoenolpyruvate; THF, tetrahydrofolate; DHF, dihydrofolate; FA, fatty acids; Fatty Ac-CoA, Fatty Acyl-Coenzyme A; GSH, glutathione; Trx, thioredoxin; NT, nucleotides.

GAPDH is modified by O-GlcNAcylation mainly at Thr172. This modification favors the oligomeric instead of the tetrameric form of the enzyme, leading to its translocation into the nucleus and to the biological activities mediated by the non-tetrameric GAPDH [99]. Indeed, while the glycolytic activity is exerted by the cytoplasmic tetrameric GAPDH, the oligomeric nuclear form of the enzyme has roles in the transcriptional control of histone gene expression, fusion of the nuclear membrane, DNA repair and maintenance of the telomere structure [100]. Although the impact of the GAPDH O-GlcNAcylation on cell metabolism has not been deeply investigated, the functional redirection of the enzyme could lead to a decrease in the aerobic glycolysis, enhancing the flux through the glycolytic branches. This might be in accordance with the effect observed for PFK1 and PKM2 O-GlcNAcylation, which directly controls their glycolytic enzymatic activity, leading to important effects for cell metabolism. The O-GlcNAcylation of PFK1 at Ser529 inhibits its activity, blocking the binding of the allosteric activator fructose-2,6-bisphosphate (F-2,6-BP) and thereby 
impeding the F-2,6-BP-mediated association in higher oligomers with enhanced catalytic activity [101]. Such an O-GlcNAcylation-mediated inhibition of PFK1 activity leads to an increase of the PPP flux, reducing the glycolysis and the lactate production [101]. Interestingly, glucose-6-phosphate dehydrogenase (G6PD), the rate-limiting enzyme of the PPP, and phosphogluconate dehydrogenase (PGD), the enzyme that converts 6-phosphogluconate to ribulose-5-phosphate in the PPP, are also regulated by $O$-GlcNAcylation $[97,98,102]$. G6PD O-GlcNAcylation causes an increased affinity for $\mathrm{NADP}^{+}$and favors its catalytically-active dimeric and tetrameric forms, consequently promoting the PPP [102]. Therefore it is evident that O-GlcNAcylation has a key role in regulating the flux of the PPP. In cancer cells, the increased level of HBP and O-GlcNAcylation leads to the up-regulation of the PPP flux, providing the cells with pentose sugars and NADPH for nucleotides and lipid biosynthesis, respectively, as well as for antioxidant glutathione and thioredoxin systems. Accordingly, the O-GlcNAcylation of PFK1 and G6PD promotes cancer cell proliferation and survival and provides a growth advantage to tumors in vivo [101,102]. O-GlcNAcylation also regulates PKM2, the main pyruvate kinase isoform expressed in cancer cells [103], leading to a decrease of its activity [104,105]. In particular, PKM2 O-GlcNAcylation at Thr405 and Ser406 destabilizes the tetrameric form, favoring the less active dimeric form [105]. Dimeric PKM2, upon the reduction of its activity, causes the accumulation of the upstream glycolytic intermediates that will enter in the glycolytic branches dedicated to cell anabolism. In addition, translocating into the nucleus induces $c-M y c$ expression and consequently up-regulation of GLUT1 and lactate dehydrogenase A (LDHA) mRNA, increasing the Warburg effect [105-107]. Therefore, in cancer cells, the enhanced HBP flux and consequently the higher level of UDP-GlcNAc, leading to an increase of the O-GlcNAcylation of the glycolytic enzyme, represents an important mechanism for the regulation of the glycolysis, of the anabolic branches originated from glycolysis and of the maintenance of the Warburg effect $[83,101,102,105]$. It should be very interesting to discover the effect of the O-GlcNAcylation on the other glycolytic enzymes found glycosylated, such as HK1.

Correlated to the evidence of an $O$-GlcNAcylation-mediated increase of the cancer cell anabolism, some enzymes of the serine biosynthesis pathway, D-3-phosphoglycerate dehydrogenase (PHGDH) and phosphoserine aminotransferase 1 (PSAT1), of the glycine cleavage system, glycine decarboxylase (GLDC), and of thymidine synthesis pathway, thymidine kinase (TK), have also been found modified by O-GlcNAcylation $[96,98,108,109]$. Unfortunately, only GLDC O-GlcNAcylation has been studied in more detail. In particular, it has been shown that the increased expression of OGT, leading to GLDC O-GlcNAcylation, promotes migration and invasion in cervical cancer cells [108]. Since the increased expression of GLDC has been identified in many tumors and its metabolic activity has been associated with tumorigenesis, metastasis and poor prognosis [110-115], it is possible to speculate that the $O$-GlcNAcylation might favor the GLDC function and the pyrimidine biosynthesis.

It is worthy of note that the O-GlcNAcylation-mediated redirection of the metabolism to the anabolic branches of the glycolysis can also favor the flux through the HBP itself, establishing a positive loop. The competition between GFPT1 and PFK1 and between the aerobic glycolysis and the branching pathways has been clarified in T cells, where the high glycolytic flux limits the UDP-GlcNAc biosynthesis as a consequence of the decrease of glucose and fructose-6-P available for HBP [116].

In addition to the glycolytic and the glycolysis-correlated pathways, lipid biosynthesis is also strictly regulated by $O$-GlcNAcylation through the modification of transcriptional factors, which will be subsequently discussed, and of some key enzymes. Recently, in a model of obese mice, a direct correlation between the expression and the activity of the fatty acid synthase (FAS) and its O-GlcNAcylation status has been identified [117]. In particular, the authors observed in these mice livers that the direct modification of FAS by $O$-GlcNAcylation increases its interaction with the deubiquitinating enzyme ubiquitin-specific protease-2A (USP2A) and prevents its degradation [117]. The USP2A-mediated stabilization of FAS has been indicated as a critical event for prostate cancer cell survival [118]. In addition, by using U2OS cells, Groves et al. have observed, in response to oxidative stress, a FAS-induced inhibition of OGA activity as 
consequence of an increased association between the two proteins [119]. All these elements suggest the existence of a regulatory loop that favors FAS activity in response to its O-GlcNAcylation.

$O$-GlcNAcylation has been identified in other metabolic enzymes such as pyruvate dehydrogenase (PDH) $[96,120,121]$, isocytrate dehydrogenase (IDH), $\alpha$-ketoglutarate dehydrogenase (OGDH), succinate dehydrogenase (SDH), malate dehydrogenase (MDH) $[96,98,120,121]$, glutamate dehydrogenase (GLUD) and aspartate aminotransferase 1 and 2 (GOT1 and GOT2) [96,120,121]. Unfortunately, for these enzymes the effect of their O-GlcNAcylation has also not yet been investigated. However, considering that enhanced glutaminolysis may also lead to a reduced availability of glutamine entering in the HBP, it should be interesting to evaluate whether the O-GlcNAcylation has an effect on the enzymes involved in the glutamine utilization. In this regard, Tan et al. observed that the disruption of the O-GlcNAcylation cycling by overexpressing both OGA and OGT enzymes, reduced the levels of various TCA cycle proteins localized in the mitochondria [122]. In addition, OGT knock-out mice as compared to wild type showed enhanced muscle PDH and MDH basal activity, suggesting that a reduction of the intracellular level of O-GlcNAcylation leads to an activation of specific TCA cycle enzymes [123].

It is worthy of note that also many subunits of the electron transport chain (ETC) are O-GlcNAcylated $[96,97,120,121,124-126]$. While the role of such an O-GlcNAcylation in cancer is still under investigation, the aberrant $O$-GlcNAcylation cycling, as well as the silencing of OGT, have been analyzed either in normal cell physiology or in other human diseases. In particular, Dillmann's group investigated the role of high-glucose-induced O-GlcNAcylation in cardiomyocites. They observed that the increased O-GlcNAcylation of the ETC proteins, including NDUFA9, UQCRC1, UQCRC2 and COXI, was associated with a lower activity of complex I, III and V and lower intracellular ATP levels and mitochondrial calcium [126]. In addition, they also observed that the O-GlcNAcylation also regulated the mitochondrial dynamics, since the increased O-GlcNAcylation of the fission protein dynamin-related protein 1 (DRP1) and of the fusion-related protein OPA1 promoted mitochondria fragmentation, associated with a decrease of the mitochondrial membrane's potential, and more generally of the ETC activity $[125,127]$. Altogether these findings suggest that high levels of the mitochondrial proteins $\mathrm{O}-\mathrm{GlcNAcylation}$ reduce mitochondrial function. On the other hand, in cardiomyocites, it has also been shown that an acute and brief overall increase of mitochondrial O-GlcNAcylation, induced by $12 \mathrm{~h}$ of treatment with the OGA inhibitor thiamet-G, has a positive effect on mitochondrial function, since an increased oxygen consumption and ATP production was observed [120]. Interestingly, in Alzheimer's disease (AD), an association between mitochondrial protein $O$-GlcNAcylation and mitochondrial activity has also been observed. In fact the impairment of ATP synthase activity observed in AD appears associated with the loss of the interaction between the ATP synthase subunit a (ATP5A) and OGT, and consequently with a reduction of ATP5A O-GlcNAcylation at Thr 432, indicating that also in this model, the O-GlcNAcylation can sustain the OXPHOS activity through the regulation of Complex $\mathrm{V}$ [124]. Altogether these findings may suggest that the detrimental effect of O-GlcNAcylation on respiration might a consequence of the chronic alteration of HBP or OGT/OGA cycling, leading to constitutive mitochondrial protein O-GlcNAcylation. Conversely, the regulated process of mitochondrial protein $O$-GlcNAcylation may represent an important mechanism of mitochondrial function control, especially in physiological conditions. We would underline that although recent evidence, in contrast to the past assumptions born with Otto Warburg's work, indicates that cancer cells need functional mitochondria for their growth and survival [128], it has been demonstrated that tumors present at least an attenuated respiration driven by oncogenes, like Ras, or environmental conditions, like hypoxia or hypoxia-like hypoxia-inducible factor 1-alpha (HIF1 $\alpha)$ overexpression [129-133]. Interestingly, these are the same conditions that are responsible for the increased HBP flux and O-GlcNAcylation levels in cancer cells $[42,43]$. Thus, the aberrant $O$-GlcNAcylation might sustain the bioenergetics modification of tumors.

Taken together, all these observations indicate the protein O-GlcNAcylation as a shaper of cellular metabolism, pointing out the essential role that the HBP and O-GlcNAcylation cycling alteration could have in driving the remodeling of cancer metabolism and bioenergetics. Considering all the metabolic 
proteins found as $O$-GlcNAcylated, whose modification has not been yet investigated, this could be considered an important open research field.

\section{O-GlcNAcylation of PKA and AMPK as Master Regulators of Cancer Cell Metabolism Downstream HBP Flux}

Cell metabolism is controlled by master regulators, typically transcriptional factors or protein kinases, which control the function of numerous metabolic targets. Among these, AMPK and PKA seem to be part of a balanced regulatory loop involving the HBP (Figure 3B). AMPK is a sensor of the cellular AMP/ATP ratio, which in response to an intracellular increase of AMP or ADP levels switches the cellular metabolism from anabolism to catabolism in order to generate especially ATP [134]. In particular, in tumors AMPK negatively regulates the Warburg effect, inhibiting the lipid biosynthesis and mTOR-mediated HIF1 $\alpha$ translation and stimulating the OXPHOS and the fatty acid oxidation [134-137]. PKA has a well-known role in regulating gluconeogenesis and lipid metabolism, mainly through the downstream transcriptional factor cAMP response element binding protein (CREB) [138-140] and has been identified as pivotal in controlling cancer cell metabolism in stress conditions, through the modulation of the glutamine metabolism, respiration and autophagy in glucose shortage and upon matrix-detachment $[19,141]$. A reciprocal regulation between the two kinases, AMPK and PKA, and the HBP has been shown. Indeed AMPK is able to inhibit GFAT activity upon phosphorylation. Such an inhibition reduces the detrimental cellular effects associated with hyperglycemia or the enhancement of intracellular protein O-GlcNAcylation, both correlated with specific human disorders [142,143]. Furthermore, AMPK phosphorylates OGT, influencing its localization and target selectivity [144]. In turn, the AMPK activity is controlled by the HBP flux through its $O$-GlcNAcylation. In this regard, Bullen et al. [144] showed that $\alpha$-and $\gamma$-subunits of AMPK were O-GlcNAcylated by OGT in vitro and that this modification correlated with higher AMPK activity. Indeed, only Thr172 phosphorylated AMPK, the active form, was modified by $O$-GlcNAcylation, thereby demonstrating a selective and additive function of the two post-translational modifications. In addition, using skeletal muscle cells, they also observed that the activity of AMPK, induced by the nutritional and energetic stress upon glucose deprivation, was reduced in response to the treatment with the OGA inhibitor Thiamet $G$, which caused a strong increase in the cellular protein $O$-GlcNAcylation [144]. Note that the latter treatment mimics either a high HBP flux or the block of the O-GlcNAcylation cycling. Therefore, this and the other published data [144-146] suggest that when there is a high availability of nutrients and the flux through the HBP is elevated, the AMPK is kept off by the active metabolism and by the high level of ATP and the low AMP/ATP ratio. Conversely, when there is a nutrient shortage, AMPK is activated and the O-GlcNAcylation promotes its function. Thus, the HBP appears to be a sensor of the nutrient availability and one of the drivers of AMPK activation under nutrient shortage.

Conversely, PKA propels the HBP flux through the direct activation of the phosphorylation of GFAT $[147,148]$ and, in addition, may favor autophagy and GlcNAc recycling, especially under stress conditions [19]. The HBP activates PKA through the O-GlcNAcylation of its catalytic subunits, up-regulating the PKA-CREB signaling [149,150]. It is worthy of note that PKA is able to negatively regulate AMPK by phosphorylating the Ser173 residue and impeding the normal activating phosphorylation at Thr172 [151,152]. Thus, as shown in Figure 3B, PKA and AMPK might constitute a cycle favoring the maintenance of the HBP flux and the anabolic metabolism in rich nutrient conditions, through the AMPK inhibition that favors the activity of PKA over AMPK. In low nutrient availability (mainly glucose shortage) the balance between the two kinases, depending on the cell context, could represent a pivotal factor driving cell glycosylation and metabolism, growth and survival. Although these findings in great part have been obtained in other cell and disease models, if translated to cancer models they could open an interesting scenario of investigation. 


\section{Regulation of Cell Metabolism by $O$-GlcNAc Modified Transcriptional Factors}

As previously described, protein glycosylation may control several cellular functions. This section will focus attention on the O-GlcNAcylation of the transcriptional factor scenario and on its impact on the regulation of cellular metabolism (Figure 4). Here we subdivide transcriptional factors according to the effect of the O-GlcNAcylation on their stability, transcriptional activation, DNA-binding ability and protein-protein interaction.

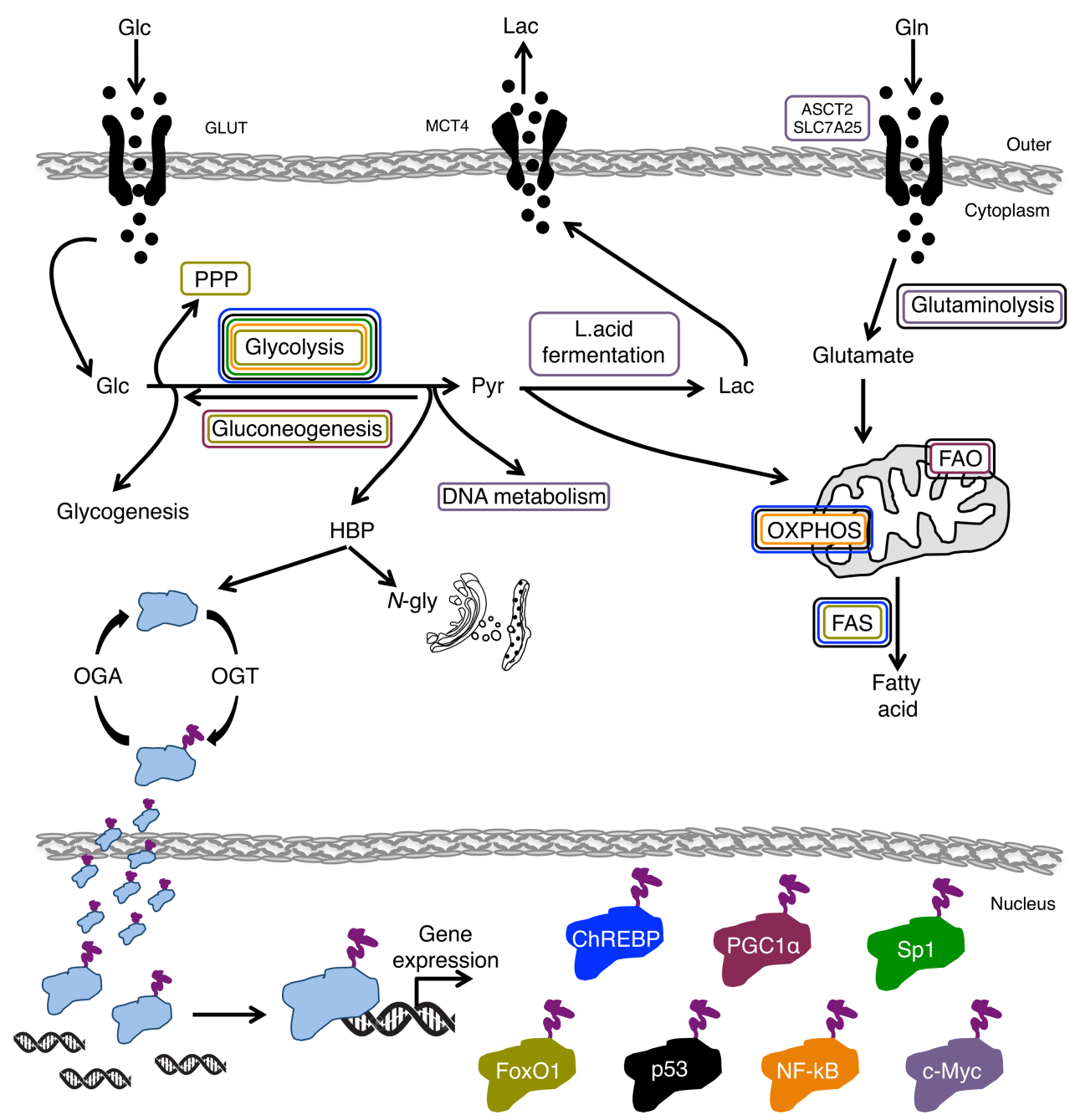

Figure 4. Schematic representation of the main metabolic pathways influenced (positively and/or negatively) by transcriptional factor $O$-GlcNAcylation. The figure depicts, from a schematic point of view, the transcriptional factors whose stability, transcriptional activation, DNA binding ability and protein-protein interaction is regulated by direct $O$-GlcNAcylation and the metabolic pathways influenced by their $O$-GlcNAcylation. The colored square around the indicated metabolic pathways is related to the specific transcriptional factor that upon $O$-GlcNAcylation is able to control the pathway.

\subsection{Protein Stability}

\subsection{1. c-Myc}

The stability of the oncogenic transcription factor c-Myc is regulated by phosphorylation and O-GlcNAcylation at Thr58, present in its transactivation domain (TAD); the aforementioned PTMs are mutually exclusive [153]. Specifically, the O-GlcNAcylation at Thr58, preventing phosphorylation by GSK3 $\beta$, blocks c-Myc ubiquitination and proteosomal degradation [154], enhancing its activation. 
c-Myc is one of the master regulators of cell metabolism due to its ability to activate the expression of several genes involved in nucleotide, glucose and glutamine metabolism and in the control of mitochondrial and ribosome biogenesis. Indeed, c-Myc promotes the gene expression of the ornitine decarboxylase $(O D C)$ [155], carboamyl-phosphate synthase (CAD) [156], dihydrofolate reductase (DHFR) [157] and thymidine kinase (TK) [158], which are all involved in DNA metabolism. In normoxia, c-Myc activation enhances the expression of some glycolytic genes such as HK2, PFK-M, ENO1 [159] and $L D H-A$ [160], and is able to confer glutamine addiction by directly up-regulating the glutamine transporters ASCT2 and SLC7A25 and indirectly up-regulating enzyme glutaminase (GLS) through the inhibition of miR-23 [161]. Glutamine can be then oxidized in the TCA cycle to generate high-energy electrons and the production of ATP, it can undergo glutaminolysis, also constituting the substrate for amino acids and GSH synthesis, and it can fuel the HBP [162].

Since its involvement in different metabolic pathways, the association between de-regulated c-Myc in tumors, the stability of which is increased upon O-GlcNAcylation, and the Warburg effect, is arguable. Accordingly, it has been reported that in human prostate cancer, a synergy between elevated $O$-GlcNAcylation levels and $c-M y c$ locus amplification occurs, leading to increased glycolysis [41]. In addition, hyper-O-GlcNAcylation and c-Myc overexpression have been associated with cisplatin resistance in human lung carcinoma [163].

\subsubsection{Peroxisome Proliferator-Activated Receptor-Gamma Coactivator- $1 \alpha$}

Peroxisome proliferator-activated receptor-gamma coactivator- $1 \alpha$ (PGC- $1 \alpha)$ belongs to a family of transcriptional co-activators involved in cellular energy metabolism, considered the master regulator of gluconeogenesis. In addition, for PGC- $1 \alpha$ a key role in mitochondrial respiration, detoxification of reactive oxygen species and fatty acid oxidation has also been reported [164].

According to the role of the altered glucose homeostasis in determining the onset of diabetes, a mechanism has been described by which the gluconeogenic genes are highly transcribed upon the direct interaction of PGC- $1 \alpha$ with a complex formed by OGT and the co-activator human factor C-1 (HCF-1) [165]. This interaction causes PGC-1 $\alpha$ O-GlcNAcylation on Ser333, preventing its degradation [166]. This stabilization leads to an enhancement of the PGC-1 $\alpha$-dependent transcription of the gluconeogenic genes, glucose 6-phosphatase (G6Pase) and phosphoenolpyruvate-carboxykinase (PEPCK). Similar results have also been obtained in a mouse model of diabetes, the $d b / d b$ mice [165]. Indeed, in these mice the knocking-down OGT and/or HCF-1 genes, leading to the disruption of the OGT/HCF-1 complex, caused an improvement of the disease [165]. The O-GlcNAcylation of PGC- $1 \alpha$ has been also involved in the regulation of thermogenesis in brown adipose tissue [167]. In fact, PGC-1 $\alpha$ O-GlcNAcylation is also associated with an increase in fatty acid oxidation [168] by the direct modulation of the expression of ETC genes [167] in association with some other transcriptional factors or co-activators (NRF1, ERR, YY1, MEF2C, PPAR) [168]. The association between PGC- $1 \alpha$ O-GlcNAcylation and its stability has been indirectly demonstrated by using an activating point mutation (C430S) in the porcine PGC-1 $\alpha$ [169]. This mutant showed an increased level of $O$-GlcNAcylation associated with higher protein stability and activity as compared to wild type protein [169]. It is important to note that PGC-1 $\alpha$ activity has been linked to different metabolic alterations of cancer cells [164]. For instance, the formation of a complex formed by PGC- $1 \alpha$, MITF and ERR $\alpha$, observed in some melanoma and breast tumors, induces an enhancement of the OXPHOS associated with major therapeutic resistance and to anchorage-independent cell growth [164]. A role of PGC- $1 \alpha$ in the activation of mitochondrial biogenesis has been also demonstrated in circulating breast tumor cells promoting metastasis [170]. In addition, some studies have also highlighted a role of PGC-1 $\alpha$ either in the enhancement of fatty acid oxidation observed in breast [171] and prostate tumors [172], or in the activation of lipogenesis in colon cancer and in ERBB2/Neu-induced breast cancer $[167,173,174]$.

In conclusion, the $O$-GlcNAcylation of PGC- $1 \alpha$ increases its stability and enhances its activity, leading to the activation of different cancer-specific metabolic pathways. 


\subsubsection{Tumor Suppressor p53}

The tumor suppressor p53 regulates cell growth and apoptosis under several cellular stress conditions through its transcriptional factor activity [175]. p53 protein stabilization and activity depend on several PTMs that regulate its ubiquitination and proteosomal degradation [176]. Recently, p53 has been defined as a sensor of the intracellular O-GlcNAcylation level, since it is regulated according to the intracellular protein O-GlcNAcylation level [177]. Mass spectrometry analysis revealed that the O-GlcNAcylation of the Ser149, localized near Thr155, is able to prevent the phosphorylation of Thr155, increasing the p53 stabilization and nuclear translocation [178]. de Queiroz et al. have demonstrated that an increase of cellular protein O-GlcNAcylation promotes p53 acetylation at Lys382, increasing p53 DNA binding and the activation of its target gene [177]. Altogether, these findings suggest that p53 O-GlcNAcylation regulates p53 stability and activity. In addition, by using a site-directed mutagenesis approach, it has been suggested that p53 O-GlcNAcylation may occur in other undefined residues, since the mutation of Ser149 does not completely abolish p53 O-GlcNAcylation [178]. Nevertheless, the role of these other residues in p53 function has not yet been defined.

It is worthy of note that the role of p53 in regulating cellular metabolism is well described. Indeed, through its transcriptional activity, it negatively regulates glycolysis and lipid biogenesis and positively regulates oxidative phosphorylation, glutaminolysis, and fatty acid oxidation (FAO) [179]. This metabolic regulation correlates with its oncosuppressive function, since it counteracts the metabolic rewiring observed in cancer cells, such as the Warburg effect. Most likely, p53 O-GlcNAcylation, by controlling its activity, is involved in the transcriptional activation of other metabolic targets associated with its oncosuppressive function, however no investigation has been conducted on this particular aspect of p53 regulation in cancer.

\subsection{Transcriptional Activity}

\section{Forkhead Box Other-1}

Forkhead box other-1 (FoxO1) is a forkhead box family member, able to control the expression of genes involved in the regulation of the cell cycle, in response to oxidative stress and apoptosis. FoxO1 appears to be a highly O-GlcNAcylated, since at least five different residues have been found to be modified by this PTM (Thr317, Ser550, Thr648, Ser654 [166] and Thr646 [180]). In addition, upon abnormal $O$-GlcNAcylation, often observed in chronic hyperglycaemia patients, FoxO1 promotes the transcription of PGC-1 $\alpha$, which in turns interacts with FoxO1, in order to activate the genes involved in hepatic gluconeogenesis, G6Pase and PEPCK, leading to further glucose production and therefore to the enhancement of FoxO1 O-GlcNAcylation [181]. Although increased FoxO1 O-GlcNAcylation correlates with its increased transcriptional activity, functional studies have indicated that only the mutation of the Thr317 residue slightly reduces FoxO1 transcriptional activity [180].

FoxO1 generally functions as a tumor suppressor in cancer [182]. Emerging evidence, indeed, reveals that FoxO1 represses glycolysis and mitochondrial respiration by inhibiting c-Myc and thus counteracting the Warburg effect [183]. Moreover, FoxO1 may negatively regulate SREBP1c-mediated fatty acid and cholesterol biosynthesis, which are up-regulated in cancer [184], by occupying and disrupting the assembly of the transcriptional initiation complex on the SREBP1c promoter [185].

The findings indicate that the O-GlcNAcylation of the two tumor suppressors FoxO1 and p53 enhances their activity; this is rather counterintuitive to the fact that cancer increases the level of protein $\mathrm{O}-\mathrm{GlcNAcylation.} \mathrm{However,} \mathrm{it} \mathrm{is} \mathrm{important} \mathrm{to} \mathrm{underline} \mathrm{that} \mathrm{both} \mathrm{p53} \mathrm{and} \mathrm{FoxO1} \mathrm{are}$ inactivated by mutation in almost all tumors or in several types of tumors, respectively [186-188]. Therefore, the O-GlcNAcylation of these two proteins may be involved in normal cell metabolism, as previously described, in other types of human diseases, as well as at an early phase of tumor development. In the near future it will be interesting to investigate the role of tumor suppressors $O$-GlcNAcylation in correlation with the metabolic changes observed in cancer, especially at the early onset. 


\subsection{Protein-Protein Interaction}

Nuclear Factor Kappa-Light-Chain-Enhancer of Activated B Cells

Nuclear factor kappa-light-chain-enhancer of activated B cells (NF-kB) is another important transcription factor involved in cancerogenesis, the activity of which is regulated by O-GlcNAcylation. For instance, in pancreatic ductal adenocarcinoma (PDAC), the mutation of the two O-GlcNAcylated sites of the NF-kB-p65 subunit, Thr352 and Th322, causes a dramatic decrease of cancer cell growth [93]. Notably, it has been reported that the O-GlcNAcylation of these two residues in NF- $\mathrm{KB}-\mathrm{p} 65$ causes a decreased binding to the IkBa protein (the inhibitor of NF- $\mathrm{BB}$ ), enhancing the NF- $\mathrm{BB}$ stability, and causing increased transcriptional activity [189]. Furthermore, in PDAC, it has been also shown that the $\mathrm{O}-\mathrm{GlcNAcylation}$ of IKK $\alpha$, a subunit of the kinase (IKK) that positively regulates NF- $\mathrm{KB}$ activity, is associated with an enhancement of its kinase activity that leads to the increased stabilization and nuclear translocation of NF-кB [93]. NF-kB's ability to regulate cell metabolism, acting both on glycolysis and OXPHOS, has also been reported [190]. In particular, NF- $\mathrm{B}$ metabolic regulation depends on the p53 genetic status. Indeed, in p53-deficent cancer cells the active NF- $\mathrm{B}$ is able to enter into mitochondria [191], where it suppresses mitochondrial gene expression and OXPHOS. Conversely, promoting nuclear GLUT3 gene expression boosts glycolysis [192]. Notably, this increased GLUT3 expression leads to enhanced glucose uptake and HBP flux that further induces NF- $\mathrm{kB}$ activity, promoting IKK stabilization through Ser733 O-GlcNAcylation. Altogether, these observations suggest that the cancer metabolic rewiring is favored by the existence of a positive feedback loop between IKK-NF-kB O-GlcNAcylation and the enhancement of the glycolysis [192].

\subsection{DNA Binding}

Carbohydrate-Responsive Element Binding Protein

Carbohydrate-responsive element binding protein (ChREBP) is a key regulator of glycolysis and lipid metabolism through its capacity to act as a transcriptional activator of both glycolytic and lipogenic genes [193,194], as well as L-pyruvate kinase (L-PK) [195], Ac-CoA carboxylase (ACC) and FAS [196].

ChREBP interacts directly with OGT [197]. Although the precise protein location of the O-GlcNAcylated residues has not been yet identified, it has been clearly shown that they are in a different position and have an opposite function with respect to the phosphorylated sites [197]. For instance, the PKA-dependent phosphorylation of ChREBP, which promotes its interaction with the 14-3-3 protein, retains the ChREBP cytosols in an inactivated status [197]. Conversely, ChREBP $\mathrm{O}-$ GlcNAcylation enhances its activity and the binding to the carbohydrate response elements (ChoRE) in the promoter region of specific metabolic target genes [198]. Although a large amount of data highlights the key role of ChREBP in hepatocytes, a growing body of literature also reveals the involvement of ChREBP in cancer. Indeed, recent studies delineate a role of ChREBP, through its transcriptional activity, in tumor initiation and in the progression of different solid and non-solid tumors [199]. A connection between ChREBP function and tumor metabolic reprogramming has also been well-established [200]. Indeed, upon ChREBP suppression, HCT116 colorectal cancer cells and HepG2 hepatoblastoma cells show a reduction of aerobic glycolysis, of lipogenesis and of nucleotide biosynthesis; conversely a concomitant increase in oxygen consumption through the activation of mitochondrial respiration has been observed. All these metabolic features correlate with decreased tumor potential [200,201].

\subsection{Subcellular Localization, Stability and Transcriptional Activity}

Specificity Protein 1

The zinc finger transcription factor specificity protein $1(\mathrm{Sp} 1)$ is the first transcription factor identified as O-GlcNAcylated [202]. Sp1 regulates cell survival, growth and angiogenesis by activating 
the transcription of specific target genes, and its abnormal expression is found to be associated with cancer development and major aggressiveness [203]. Sp1 subcellular localization, stability and transcriptional activity are regulated by PTMs, including O-GlcNAcylation [204]. The analysis of the Sp1 $\mathrm{O}$-GlcNAcylation status has permitted the identification of at least eight O-GlcNAcylated residues [205]. These sites, identified in the zinc finger DNA-binding domain and in the domain necessary for the interaction with other transcription factors or co-activators, control either the Sp1 DNA binding capacity or its basal transcriptional activity [206,207]. Nevertheless, Sp1 O-GlcNAcylation, as indicated in different reports, has been associated either with negative or positive transcriptional activity with regard to cell metabolism [202,208,209]. For instance, it has been shown in HEK293 cells, that Sp1 O-GlcNAcylation leads to the negative transcriptional regulation of the glycolytic genes. Indeed, the expression of $O$-GlcNAcylation mutants of Sp1 causes the up-regulation of several mRNA encoding for glycolytic enzymes, such as PFK- $L$ and PFK-M, triose phosphate isomerase (TPI), GAPDH, phosphoglycerate kinase1 (PGK1), phosphoglycerate mutase 1 (PGAM1), ENO1 and PK-M [210]. Penque et al. have shown that in the hyperinsulinemic condition, the activation of Sp1 by O-GlcNAcylation is associated with a cholesterolgenic response in murine 3T3-L1 preadipocytes. Indeed, O-GlcNAcylated Sp1 induces the expression of the sterol response element-binding protein 1 (SREBP1) and of 3-hydroxy-3-methyl-glutaryl-coenzyme A reductase (Hmgcr), which increase the amount of plasma membrane cholesterol, and negatively affect the correct GLUT4 membrane localization [211-213]. Another example of the relation between Sp1 $O$-GlcNAcylation and metabolism has been observed in the Caco-2/TC7 cell line (intestinal enterocytes) upon cell treatment with glutamine or glucosamine. Both treatments, increasing Sp1 O-GlcNAcylation, permit the transcriptional activation of the argininosuccinate synthase (ASS) gene [214]. This observation underlines the important role of Sp1 in cancer metabolism. Indeed, it has been reported that arginine depletion, a consequence of the ASS1 silencing in several cancer cell lines, causes a reduction in aerobic glycolysis and a parallel increase in serine biosynthesis, glutamine anaplerosis and oxidative phosphorylation [215].

The involvement of Sp1 in cancer metabolic rewiring has been further shown in different reports. Sp1 activation in colon and prostate cancers is associated with the activation of several genes involved in fatty acid synthesis, such as FAS [216], ATP citrate lyase (ACLY) and Acetyl-CoA carboxylase $(A C A C A)$ [217]. In addition, Sp1 expression and activity has also been associated with the overexpression of the human testis-specific lactate dehydrogenase c gene ( $h L D H C)$ in lung, melanoma and breast cancer $[218,219]$. Importantly, the abnormal activation of Sp1 has been identified in several types of tumors such as pancreas [220], gastric [221] and epithelial [222]. According to these data, Sp1 O-GlcNAcylation, increasing its activity and stability, may be directly involved in the cancer metabolic rewiring associated with cancer onset.

In conclusion, all aforementioned reports highlight the pivotal role of $O$-GlcNAcylation and hence of HBP flux in controlling cell metabolism via the regulation of the key transcription factors involved either in the regulation of physiological cell metabolism or, when deregulated, in human diseases such as cancer.

\section{Concluding Remarks}

Tumor metabolic reprogramming is considered one important cancer hallmark. For this reason, recently more and more researchers have addressed their studies to the identification of these cancer-specific metabolic features as well as to the definition of their role in tumor onset, maintenance and aggressiveness. The overwhelming number of findings, shedding new light on cancer metabolism, has also unlocked the possibility of targeting the metabolism for cancer therapy. Among the different metabolic pathways identified in cancer, an important role has been assigned to the HBP. In fact, the HBP, as described in this review, may be considered the only metabolic route able to continuously monitor the cellular nutrient status and to generate a "signaling" metabolite, the end product UDP-GlcNAc, able to lead to a fine adjustment of the cellular metabolism in direct correlation with nutrient variations. Such a prominent role in controlling cell metabolism has linked its alterations to the 
etiology of different human diseases such metabolic syndromes, i.e., diabetes [223], neurodegenerative diseases [224], aging [225] and cancer. Regarding cancer, we reviewed how this metabolic pathway may be involved in the metabolic reprogramming of cancer cells. Indeed, first, we defined its role as a nutrient sensor, describing how the main intracellular metabolites, namely glucose, amino acids and fatty acids are able to influence the HBP flux. Second, we described how the change of the HBP flux influences nutrient transporter expression, stability, affinity for the substrate and membrane targeting, through the modulation of their $N$-glycosylation status. Third, we emphasized the positive and negative role of $O$-GlcNAcylation in the regulation of glycolysis, PPP, fatty acid metabolism and mitochondrial activity, either by the direct PTM of the different proteins involved in the above metabolic pathways, or indirectly, through the O-GlcNAcylation of transcriptional factors acting in cancer cell metabolism rewiring.

One interesting extension of these observations is that HBP may be considered the main cellular nutrient sensor pathway. In fact, compared with other sensor pathways, such as AMPK and mTOR, which act in response to a reduction of ATP or to an alteration of the amino acid levels, respectively, the HBP senses all the main types of intracellular nutrients leading to an orchestrated metabolic response. In addition, whilst our understanding of nutrient sensing mechanisms is far from complete, we can also argue that HBP is the most rapid and upstream metabolic pathway able to respond to nutrient variations. In fact, the HBP flux that is modulated by either a surplus or a shortfall of nutrients must be on the top of the sensing signaling cascade in such a way as to rapidly modulate cellular bioenergetics and metabolism.

Given this important role in metabolism, it does not appear surprising that in cancer cells this pathway is often up-regulated either in terms of gene and protein expression or in terms of flux. As we reviewed, its activation entirely resembles the most important metabolic alterations observed in tumors, such as increased glycolysis, increased glutamine utilization, increased fatty acid synthesis as well as great changes in mitochondrial bioenergetics. In our opinion, in the near future studies regarding the connection between HBP and cancer will increase, since several points still need to be addressed. For example, it will be useful to have tumor/cell profiles of protein glycosylation under normal growth conditions and nutrient perturbed conditions, which may help to define the glycosylation signatures associated with the cancer's ability to adapt to nutrient variations. Furthermore, the identification of the other transcription factors will be useful, with particular attention dedicated to the oncogenic factors whose $O$-GlcNAcylation may alter cell metabolism. It will be useful as well to investigate the role of nutritional load or nutrient processing, for instance the role of bacterial flora, on the HBP activation and hence in the development of cancer, i.e., colon cancer. Finally, it will be useful to identify and validate novel putative HBP inhibitors either as tools for a deeper understanding of this pathway or as new drugs for cancer therapy. The latter is a tremendously interesting field, since HBP is involved in all the cancer hallmarks [226]. In fact, as some recent publications clearly highlighted [26,227,228], the inhibition of HBP or one of its two branches, controlling $N$-glycosylation or O-GlcNAcylation respectively, may help to develop new therapies for human cancer. Undoubtedly, these approaches will bring a substantial value to the field of cancer metabolic rewiring, but, in perspective, they could also be applied to other human diseases, such as neurodegeneration or aging.

We wish to apologize to all the authors who were not cited in this review. We tried to identify all the references linked to the subject of the review, but probably missed some authors. However we believe that the articles reviewed are good examples supporting a role of HBP in cancer metabolism rewiring.

Acknowledgments: This work was supported by a grant from the Associazione Italiana per la Ricerca sul Cancro (A.I.R.C, IG2014 Id.15364) and Fondo di Ateneo (FAR) to F.C. F.R was supported by an A.I.R.C. fellowship. F.R. and R.P. are supported by fellowships from MIUR. We are grateful to Neil Campbell for manuscript English editing.

Conflicts of Interest: The authors declare no conflict of interest. 


\section{References}

1. Warburg, O.; Wind, F.; Negelein, E. The Metabolism of Tumors in the Body. J. Gen. Physiol. 1927, 8, 519-530. [CrossRef] [PubMed]

2. DeBerardinis, R.J.; Chandel, N.S. Fundamentals of cancer metabolism. Sci. Adv. 2016, 2, e1600200. [CrossRef] [PubMed]

3. Pavlova, N.N.; Thompson, C.B. The Emerging Hallmarks of Cancer Metabolism. Cell Metab. 2016, 23, $27-47$. [CrossRef] [PubMed]

4. Lau, K.S.; Dennis, J.W. N-Glycans in cancer progression. Glycobiology 2008, 18, 750-760. [CrossRef] [PubMed]

5. Love, D.C.; Hanover, J.A. The hexosamine signaling pathway: Deciphering the "O-GlcNAc code". Sci. STKE Signal Transduct. Knowl. Environ. 2005, 2005, re13. [CrossRef] [PubMed]

6. Moremen, K.W.; Tiemeyer, M.; Nairn, A.V. Vertebrate protein glycosylation: Diversity, synthesis and function. Nat. Rev. Mol. Cell Biol. 2012, 13, 448-462. [CrossRef] [PubMed]

7. Yang, X.; Qian, K. Protein O-GlcNAcylation: Emerging mechanisms and functions. Nat. Rev. Mol. Cell Biol. 2017, 18, 452-465. [CrossRef] [PubMed]

8. Hart, G.W.; Slawson, C.; Ramirez-Correa, G.; Lagerlof, O. Cross talk between O-GlcNAcylation and phosphorylation: Roles in signaling, transcription, and chronic disease. Annu. Rev. Biochem. 2011, 80, 825-858. [CrossRef] [PubMed]

9. Marshall, S.; Bacote, V.; Traxinger, R.R. Discovery of a metabolic pathway mediating glucose-induced desensitization of the glucose transport system. Role of hexosamine biosynthesis in the induction of insulin resistance. J. Biol. Chem. 1991, 266, 4706-4712. [PubMed]

10. Ryczko, M.C.; Pawling, J.; Chen, R.; Abdel Rahman, A.M.; Yau, K.; Copeland, J.K.; Zhang, C.; Surendra, A.; Guttman, D.S.; Figeys, D.; et al. Metabolic Reprogramming by Hexosamine Biosynthetic and Golgi N-Glycan Branching Pathways. Sci. Rep. 2016, 6, 23043. [CrossRef] [PubMed]

11. Marshall, S.; Nadeau, O.; Yamasaki, K. Dynamic actions of glucose and glucosamine on hexosamine biosynthesis in isolated adipocytes: Differential effects on glucosamine 6-phosphate, UDP-N-acetylglucosamine, and ATP levels. J. Biol. Chem. 2004, 279, 35313-35319. [CrossRef] [PubMed]

12. Schleicher, E.D.; Weigert, C. Role of the hexosamine biosynthetic pathway in diabetic nephropathy. Kidney Int. 2000, 58 (Suppl. 77), S13-S18. [CrossRef]

13. Vasconcelos-Dos-Santos, A.; Loponte, H.F.; Mantuano, N.R.; Oliveira, I.A.; de Paula, I.F.; Teixeira, L.K.; de-Freitas-Junior, J.C.; Gondim, K.C.; Heise, N.; Mohana-Borges, R.; et al. Hyperglycemia exacerbates colon cancer malignancy through hexosamine biosynthetic pathway. Oncogenesis 2017, 6, e306. [CrossRef] [PubMed]

14. Abdel Rahman, A.M.; Ryczko, M.; Pawling, J.; Dennis, J.W. Probing the hexosamine biosynthetic pathway in human tumor cells by multitargeted tandem mass spectrometry. ACS Chem. Biol. 2013, 8, 2053-2062. [CrossRef] [PubMed]

15. Wellen, K.E.; Lu, C.; Mancuso, A.; Lemons, J.M.; Ryczko, M.; Dennis, J.W.; Rabinowitz, J.D.; Coller, H.A.; Thompson, C.B. The hexosamine biosynthetic pathway couples growth factor-induced glutamine uptake to glucose metabolism. Genes Dev. 2010, 24, 2784-2799. [CrossRef] [PubMed]

16. Palorini, R.; Cammarata, F.P.; Balestrieri, C.; Monestiroli, A.; Vasso, M.; Gelfi, C.; Alberghina, L.; Chiaradonna, F. Glucose starvation induces cell death in K-ras-transformed cells by interfering with the hexosamine biosynthesis pathway and activating the unfolded protein response. Cell Death Dis. 2013, 4, e732. [CrossRef] [PubMed]

17. Taylor, R.P.; Geisler, T.S.; Chambers, J.H.; McClain, D.A. Up-regulation of O-GlcNAc transferase with glucose deprivation in HepG2 cells is mediated by decreased hexosamine pathway flux. J. Biol. Chem. 2009, 284, 3425-3432. [CrossRef] [PubMed]

18. Nakajima, K.; Kitazume, S.; Angata, T.; Fujinawa, R.; Ohtsubo, K.; Miyoshi, E.; Taniguchi, N. Simultaneous determination of nucleotide sugars with ion-pair reversed-phase HPLC. Glycobiology 2010, 20, 865-871. [CrossRef] [PubMed]

19. Palorini, R.; Votta, G.; Pirola, Y.; De Vitto, H.; De Palma, S.; Airoldi, C.; Vasso, M.; Ricciardiello, F.; Lombardi, P.P.; Cirulli, C.; et al. Protein Kinase A Activation Promotes Cancer Cell Resistance to Glucose Starvation and Anoikis. PLoS Genet. 2016, 12, e1005931. [CrossRef] [PubMed] 
20. Chaveroux, C.; Sarcinelli, C.; Barbet, V.; Belfeki, S.; Barthelaix, A.; Ferraro-Peyret, C.; Lebecque, S.; Renno, T.; Bruhat, A.; Fafournoux, P.; et al. Nutrient shortage triggers the hexosamine biosynthetic pathway via the GCN2-ATF4 signalling pathway. Sci. Rep. 2016, 6, 27278. [CrossRef] [PubMed]

21. Taylor, R.P.; Parker, G.J.; Hazel, M.W.; Soesanto, Y.; Fuller, W.; Yazzie, M.J.; McClain, D.A. Glucose deprivation stimulates $\mathrm{O}$-GlcNAc modification of proteins through up-regulation of O-linked $N$-acetylglucosaminyltransferase. J. Biol. Chem. 2008, 283, 6050-6057. [CrossRef] [PubMed]

22. Zou, L.; Zhu-Mauldin, X.; Marchase, R.B.; Paterson, A.J.; Liu, J.; Yang, Q.; Chatham, J.C. Glucose deprivation-induced increase in protein $O$-GlcNAcylation in cardiomyocytes is calcium-dependent. J. Biol. Chem. 2012, 287, 34419-34431. [CrossRef] [PubMed]

23. Hamiel, C.R.; Pinto, S.; Hau, A.; Wischmeyer, P.E. Glutamine enhances heat shock protein 70 expression via increased hexosamine biosynthetic pathway activity. Am. J. Physiol. Cell Physiol. 2009, 297, C1509-C1519. [CrossRef] [PubMed]

24. Swamy, M.; Pathak, S.; Grzes, K.M.; Damerow, S.; Sinclair, L.V.; van Aalten, D.M.; Cantrell, D.A. Glucose and glutamine fuel protein O-GlcNAcylation to control T cell self-renewal and malignancy. Nat. Immunol. 2016, 17, 712-720. [CrossRef] [PubMed]

25. Liu, J.; Marchase, R.B.; Chatham, J.C. Increased O-GlcNAc levels during reperfusion lead to improved functional recovery and reduced calpain proteolysis. Am. J. Physiol. Heart Circ. Physiol. 2007, 293, H1391-H1399. [CrossRef] [PubMed]

26. Pham, L.V.; Bryant, J.L.; Mendez, R.; Chen, J.; Tamayo, A.T.; Xu-Monette, Z.Y.; Young, K.H.; Manyam, G.C.; Yang, D.; Medeiros, L.J.; et al. Targeting the hexosamine biosynthetic pathway and O-linked $\mathrm{N}$-acetylglucosamine cycling for therapeutic and imaging capabilities in diffuse large B-cell lymphoma. Oncotarget 2016, 7, 80599-80611. [CrossRef] [PubMed]

27. Hinderlich, S.; Berger, M.; Schwarzkopf, M.; Effertz, K.; Reutter, W. Molecular cloning and characterization of murine and human $N$-acetylglucosamine kinase. Eur. J. Biochem. 2000, 267, 3301-3308. [CrossRef] [PubMed]

28. Weihofen, W.A.; Berger, M.; Chen, H.; Saenger, W.; Hinderlich, S. Structures of human N-Acetylglucosamine kinase in two complexes with $\mathrm{N}$-Acetylglucosamine and with ADP/glucose: Insights into substrate specificity and regulation. J. Mol. Biol. 2006, 364, 388-399. [CrossRef] [PubMed]

29. Grigorian, A.; Lee, S.U.; Tian, W.; Chen, I.J.; Gao, G.; Mendelsohn, R.; Dennis, J.W.; Demetriou, M. Control of T Cell-mediated autoimmunity by metabolite flux to N-glycan biosynthesis. J. Biol. Chem. 2007, 282, 20027-20035. [CrossRef] [PubMed]

30. Hawkins, M.; Barzilai, N.; Liu, R.; Hu, M.; Chen, W.; Rossetti, L. Role of the glucosamine pathway in fat-induced insulin resistance. J. Clin. Investig. 1997, 99, 2173-2182. [CrossRef] [PubMed]

31. Weigert, C.; Klopfer, K.; Kausch, C.; Brodbeck, K.; Stumvoll, M.; Haring, H.U.; Schleicher, E.D. Palmitate-induced activation of the hexosamine pathway in human myotubes: Increased expression of glutamine:fructose-6-phosphate aminotransferase. Diabetes 2003, 52, 650-656. [CrossRef] [PubMed]

32. Anastasiou, D. Tumour microenvironment factors shaping the cancer metabolism landscape. Br. J. Cancer 2016, 116, 277-286. [CrossRef] [PubMed]

33. Lynch, T.P.; Reginato, M.J. O-GlcNAc transferase: A sweet new cancer target. Cell Cycle 2011, 10, $1712-1713$. [CrossRef] [PubMed]

34. Ma, Z.; Vosseller, K. Cancer metabolism and elevated O-GlcNAc in oncogenic signaling. J. Biol. Chem. 2014, 289, 34457-34465. [CrossRef] [PubMed]

35. Pinho, S.S.; Reis, C.A. Glycosylation in cancer: Mechanisms and clinical implications. Nat. Rev. Cancer 2015, 15, 540-555. [CrossRef] [PubMed]

36. Taparra, K.; Tran, P.T.; Zachara, N.E. Hijacking the Hexosamine Biosynthetic Pathway to Promote EMT-Mediated Neoplastic Phenotypes. Front. Oncol. 2016, 6, 85. [CrossRef] [PubMed]

37. Kornfeld, S.; Kornfeld, R.; Neufeld, E.F.; O’Brien, P.J. The Feedback Control of Sugar Nucleotide Biosynthesis in Liver. Proc. Natl. Acad. Sci. USA 1964, 52, 371-379. [CrossRef] [PubMed]

38. McKnight, G.L.; Mudri, S.L.; Mathewes, S.L.; Traxinger, R.R.; Marshall, S.; Sheppard, P.O.; O’Hara, P.J. Molecular cloning, cDNA sequence, and bacterial expression of human glutamine:fructose-6-phosphate amidotransferase. J. Biol. Chem. 1992, 267, 25208-25212. [PubMed] 
39. Srinivasan, V.; Sandhya, N.; Sampathkumar, R.; Farooq, S.; Mohan, V.; Balasubramanyam, M. Glutamine fructose6-phosphate amidotransferase (GFAT) gene expression and activity in patients with type 2 diabetes: Inter-relationships with hyperglycaemia and oxidative stress. Clin. Biochem. 2007, 40, 952-957. [CrossRef] [PubMed]

40. Paterson, A.J.; Kudlow, J.E. Regulation of glutamine:fructose-6-phosphate amidotransferase gene transcription by epidermal growth factor and glucose. Endocrinology 1995, 136, 2809-2816. [CrossRef] [PubMed]

41. Itkonen, H.M.; Minner, S.; Guldvik, I.J.; Sandmann, M.J.; Tsourlakis, M.C.; Berge, V.; Svindland, A.; Schlomm, T.; Mills, I.G. O-GlcNAc transferase integrates metabolic pathways to regulate the stability of c-MYC in human prostate cancer cells. Cancer Res. 2013, 73, 5277-5287. [CrossRef] [PubMed]

42. Guillaumond, F.; Leca, J.; Olivares, O.; Lavaut, M.N.; Vidal, N.; Berthezene, P.; Dusetti, N.J.; Loncle, C.; Calvo, E.; Turrini, O.; et al. Strengthened glycolysis under hypoxia supports tumor symbiosis and hexosamine biosynthesis in pancreatic adenocarcinoma. Proc. Natl. Acad. Sci. USA 2013, 110, 3919-3924. [CrossRef] [PubMed]

43. Ying, H.; Kimmelman, A.C.; Lyssiotis, C.A.; Hua, S.; Chu, G.C.; Fletcher-Sananikone, E.; Locasale, J.W.; Son, J.; Zhang, H.; Coloff, J.L.; et al. Oncogenic Kras maintains pancreatic tumors through regulation of anabolic glucose metabolism. Cell 2012, 149, 656-670. [CrossRef] [PubMed]

44. Dennis, J.W.; Nabi, I.R.; Demetriou, M. Metabolism, cell surface organization, and disease. Cell 2009, 139, 1229-1241. [CrossRef] [PubMed]

45. Ganapathy, V.; Thangaraju, M.; Prasad, P.D. Nutrient transporters in cancer: Relevance to Warburg hypothesis and beyond. Pharmacol. Ther. 2009, 121, 29-40. [CrossRef] [PubMed]

46. McCracken, A.N.; Edinger, A.L. Nutrient transporters: The Achilles' heel of anabolism. Trends Endocrinol. Metab. TEM 2013, 24, 200-208. [CrossRef] [PubMed]

47. Barron, C.C.; Bilan, P.J.; Tsakiridis, T.; Tsiani, E. Facilitative glucose transporters: Implications for cancer detection, prognosis and treatment. Metab. Clin. Exp. 2016, 65, 124-139. [CrossRef] [PubMed]

48. Asano, T.; Katagiri, H.; Takata, K.; Lin, J.L.; Ishihara, H.; Inukai, K.; Tsukuda, K.; Kikuchi, M.; Hirano, H.; Yazaki, Y.; et al. The role of N-glycosylation of GLUT1 for glucose transport activity. J. Biol. Chem. 1991, 266, 24632-24636. [PubMed]

49. Asano, T.; Takata, K.; Katagiri, H.; Ishihara, H.; Inukai, K.; Anai, M.; Hirano, H.; Yazaki, Y.; Oka, Y. The role of N-glycosylation in the targeting and stability of GLUT1 glucose transporter. FEBS Lett. 1993, 324, 258-261. [CrossRef]

50. Onetti, R.; Baulida, J.; Bassols, A. Increased glucose transport in ras-transformed fibroblasts: A possible role for N-glycosylation of GLUT1. FEBS Lett. 1997, 407, 267-270. [CrossRef]

51. Samih, N.; Hovsepian, S.; Aouani, A.; Lombardo, D.; Fayet, G. Glut-1 translocation in FRTL-5 thyroid cells: Role of phosphatidylinositol 3-kinase and N-glycosylation. Endocrinology 2000, 141, 4146-4155. [CrossRef] [PubMed]

52. Samih, N.; Hovsepian, S.; Notel, F.; Prorok, M.; Zattara-Cannoni, H.; Mathieu, S.; Lombardo, D.; Fayet, G.; El-Battari, A. The impact of $N$ - and $O$-glycosylation on the functions of Glut-1 transporter in human thyroid anaplastic cells. Biochim. Biophys. Acta 2003, 1621, 92-101. [CrossRef]

53. Pratt, S.E.; Germinario, R.J. Differential glycosylation of the glucose transporter coincides with enhanced sugar transport in respiration deficient cells. Biochem. Biophys. Res. Commun. 1994, 200, 1313-1320. [CrossRef] [PubMed]

54. Hauguel-de Mouzon, S.; Challier, J.C.; Kacemi, A.; Cauzac, M.; Malek, A.; Girard, J. The GLUT3 glucose transporter isoform is differentially expressed within human placental cell types. J. Clin. Endocrinol. Metab. 1997, 82, 2689-2694. [CrossRef] [PubMed]

55. Arthur, S.; Coon, S.; Kekuda, R.; Sundaram, U. Regulation of sodium glucose co-transporter SGLT1 through altered glycosylation in the intestinal epithelial cells. Biochim. Biophys. Acta 2014, 1838, 1208-1214. [CrossRef] [PubMed]

56. Haga, Y.; Ishii, K.; Suzuki, T. N-glycosylation is critical for the stability and intracellular trafficking of glucose transporter GLUT4. J. Biol. Chem. 2011, 286, 31320-31327. [CrossRef] [PubMed]

57. Le Floch, R.; Chiche, J.; Marchiq, I.; Naiken, T.; Ilc, K.; Murray, C.M.; Critchlow, S.E.; Roux, D.; Simon, M.P.; Pouyssegur, J. CD147 subunit of lactate/H+ symporters MCT1 and hypoxia-inducible MCT4 is critical for energetics and growth of glycolytic tumors. Proc. Natl. Acad. Sci. USA 2011, 108, 16663-16668. [CrossRef] [PubMed] 
58. Muramatsu, T. Basigin (CD147), a multifunctional transmembrane glycoprotein with various binding partners. J. Biochem. 2016, 159, 481-490. [CrossRef] [PubMed]

59. Moloughney, J.G.; Kim, P.K.; Vega-Cotto, N.M.; Wu, C.C.; Zhang, S.; Adlam, M.; Lynch, T.; Chou, P.C.; Rabinowitz, J.D.; Werlen, G.; et al. mTORC2 Responds to Glutamine Catabolite Levels to Modulate the Hexosamine Biosynthesis Enzyme GFAT1. Mol. Cell 2016, 63, 811-826. [CrossRef] [PubMed]

60. Fuchs, B.C.; Bode, B.P. Amino acid transporters ASCT2 and LAT1 in cancer: Partners in crime? Semin. Cancer Biol. 2005, 15, 254-266. [CrossRef] [PubMed]

61. Gaglio, D.; Metallo, C.M.; Gameiro, P.A.; Hiller, K.; Danna, L.S.; Balestrieri, C.; Alberghina, L.; Stephanopoulos, G.; Chiaradonna, F. Oncogenic K-Ras decouples glucose and glutamine metabolism to support cancer cell growth. Mol. Syst. Biol. 2011, 7, 523. [CrossRef] [PubMed]

62. Console, L.; Scalise, M.; Tarmakova, Z.; Coe, I.R.; Indiveri, C. N-linked glycosylation of human SLC1A5 (ASCT2) transporter is critical for trafficking to membrane. Biochim. Biophys. Acta 2015, 1853, 1636-1645. [CrossRef] [PubMed]

63. Polet, F.; Martherus, R.; Corbet, C.; Pinto, A.; Feron, O. Inhibition of glucose metabolism prevents glycosylation of the glutamine transporter ASCT2 and promotes compensatory LAT1 upregulation in leukemia cells. Oncotarget 2016, 7, 46371-46383. [CrossRef] [PubMed]

64. Santiago-Gomez, A.; Barrasa, J.I.; Olmo, N.; Lecona, E.; Burghardt, H.; Palacin, M.; Lizarbe, M.A.; Turnay, J. 4F2hc-silencing impairs tumorigenicity of HeLa cells via modulation of galectin-3 and beta-catenin signaling, and MMP-2 expression. Biochim. Biophys. Acta 2013, 1833, 2045-2056. [CrossRef] [PubMed]

65. Yang, Y.; Toy, W.; Choong, L.Y.; Hou, P.; Ashktorab, H.; Smoot, D.T.; Yeoh, K.G.; Lim, Y.P. Discovery of SLC3A2 cell membrane protein as a potential gastric cancer biomarker: Implications in molecular imaging. J. Proteome Res. 2012, 11, 5736-5747. [CrossRef] [PubMed]

66. Xiao, H.; Wu, R. Quantitative investigation of human cell surface N-glycoprotein dynamics. Chem. Sci. 2017, 8, 268-277. [CrossRef] [PubMed]

67. Fei, F.; Li, X.; Xu, L.; Li, D.; Zhang, Z.; Guo, X.; Yang, H.; Chen, Z.; Xing, J. CD147-CD98hc complex contributes to poor prognosis of non-small cell lung cancer patients through promoting cell proliferation via the PI3K/Akt signaling pathway. Ann. Surg. Oncol. 2014, 21, 4359-4368. [CrossRef] [PubMed]

68. Xu, D.; Hemler, M.E. Metabolic activation-related CD147-CD98 complex. Mol. Cell. Proteom. 2005, 4, 1061-1071. [CrossRef] [PubMed]

69. Melone, M.A.B.; Valentino, A.; Margarucci, S.; Galderisi, U.; Giordano, A.; Peluso, G. The carnitine system and cancer metabolic plasticity. Cell Death Dis. 2018, 9, 228. [CrossRef] [PubMed]

70. Wang, C.; Uray, I.P.; Mazumdar, A.; Mayer, J.A.; Brown, P.H. SLC22A5/OCTN2 expression in breast cancer is induced by estrogen via a novel intronic estrogen-response element (ERE). Breast Cancer Res. Treat. 2012, 134, 101-115. [CrossRef] [PubMed]

71. Longo, N.; Frigeni, M.; Pasquali, M. Carnitine transport and fatty acid oxidation. Biochim. Biophys. Acta 2016, 1863, 2422-2435. [CrossRef] [PubMed]

72. Filippo, C.A.; Ardon, O.; Longo, N. Glycosylation of the OCTN2 carnitine transporter: Study of natural mutations identified in patients with primary carnitine deficiency. Biochim. Biophys. Acta 2011, 1812, 312-320. [CrossRef] [PubMed]

73. Fahie, K.; Zachara, N.E. Molecular Functions of Glycoconjugates in Autophagy. J. Mol. Biol. 2016, 428, 3305-3324. [CrossRef] [PubMed]

74. Xie, Y.; Kang, R.; Sun, X.; Zhong, M.; Huang, J.; Klionsky, D.J.; Tang, D. Posttranslational modification of autophagy-related proteins in macroautophagy. Autophagy 2015, 11, 28-45. [CrossRef] [PubMed]

75. Young, A.R.; Chan, E.Y.; Hu, X.W.; Kochl, R.; Crawshaw, S.G.; High, S.; Hailey, D.W.; Lippincott-Schwartz, J.; Tooze, S.A. Starvation and ULK1-dependent cycling of mammalian Atg9 between the TGN and endosomes. J. Cell Sci. 2006, 119, 3888-3900. [CrossRef] [PubMed]

76. Li, J.; Deffieu, M.S.; Lee, P.L.; Saha, P.; Pfeffer, S.R. Glycosylation inhibition reduces cholesterol accumulation in NPC1 protein-deficient cells. Proc. Natl. Acad. Sci. USA 2015, 112, 14876-14881. [CrossRef] [PubMed]

77. Tan, K.P.; Ho, M.Y.; Cho, H.C.; Yu, J.; Hung, J.T.; Yu, A.L. Fucosylation of LAMP-1 and LAMP-2 by FUT1 correlates with lysosomal positioning and autophagic flux of breast cancer cells. Cell Death Dis. 2016, 7, e2347. [CrossRef] [PubMed] 
78. Leney, A.C.; El Atmioui, D.; Wu, W.; Ovaa, H.; Heck, A.J.R. Elucidating crosstalk mechanisms between phosphorylation and O-GlcNAcylation. Proc. Natl. Acad. Sci. USA 2017, 114, E7255-E7261. [CrossRef] [PubMed]

79. Fardini, Y.; Dehennaut, V.; Lefebvre, T.; Issad, T. O-GlcNAcylation: A New Cancer Hallmark? Front. Endocrinol. 2013, 4, 99. [CrossRef] [PubMed]

80. De Queiroz, R.M.; Carvalho, E.; Dias, W.B. O-GlcNAcylation: The Sweet Side of the Cancer. Front. Oncol. 2014, 4, 132. [CrossRef] [PubMed]

81. Ferrer, C.M.; Sodi, V.L.; Reginato, M.J. O-GlcNAcylation in Cancer Biology: Linking Metabolism and Signaling. J. Mol. Biol. 2016, 428, 3282-3294. [CrossRef] [PubMed]

82. Caldwell, S.A.; Jackson, S.R.; Shahriari, K.S.; Lynch, T.P.; Sethi, G.; Walker, S.; Vosseller, K.; Reginato, M.J. Nutrient sensor $\mathrm{O}$-GlcNAc transferase regulates breast cancer tumorigenesis through targeting of the oncogenic transcription factor FoxM1. Oncogene 2010, 29, 2831-2842. [CrossRef] [PubMed]

83. Champattanachai, V.; Netsirisawan, P.; Chaiyawat, P.; Phueaouan, T.; Charoenwattanasatien, R.; Chokchaichamnankit, D.; Punyarit, P.; Srisomsap, C.; Svasti, J. Proteomic analysis and abrogated expression of O-GlcNAcylated proteins associated with primary breast cancer. Proteomics 2013, 13, 2088-2099. [CrossRef] [PubMed]

84. Dahl, E.; Sadr-Nabavi, A.; Klopocki, E.; Betz, B.; Grube, S.; Kreutzfeld, R.; Himmelfarb, M.; An, H.X.; Gelling, S.; Klaman, I.; et al. Systematic identification and molecular characterization of genes differentially expressed in breast and ovarian cancer. J. Pathol. 2005, 205, 21-28. [CrossRef] [PubMed]

85. Gu, Y.; Mi, W.; Ge, Y.; Liu, H.; Fan, Q.; Han, C.; Yang, J.; Han, F.; Lu, X.; Yu, W. GlcNAcylation plays an essential role in breast cancer metastasis. Cancer Res. 2010, 70, 6344-6351. [CrossRef] [PubMed]

86. Krzeslak, A.; Forma, E.; Bernaciak, M.; Romanowicz, H.; Brys, M. Gene expression of O-GlcNAc cycling enzymes in human breast cancers. Clin. Exp. Med. 2012, 12, 61-65. [CrossRef] [PubMed]

87. Mi, W.; Gu, Y.; Han, C.; Liu, H.; Fan, Q.; Zhang, X.; Cong, Q.; Yu, W. O-GlcNAcylation is a novel regulator of lung and colon cancer malignancy. Biochim. Biophys. Acta 2011, 1812, 514-519. [CrossRef] [PubMed]

88. Phueaouan, T.; Chaiyawat, P.; Netsirisawan, P.; Chokchaichamnankit, D.; Punyarit, P.; Srisomsap, C.; Svasti, J.; Champattanachai, V. Aberrant $\mathrm{O}$-GlcNAc-modified proteins expressed in primary colorectal cancer. Oncol. Rep. 2013, 30, 2929-2936. [CrossRef] [PubMed]

89. Zhu, Q.; Zhou, L.; Yang, Z.; Lai, M.; Xie, H.; Wu, L.; Xing, C.; Zhang, F.; Zheng, S. O-GlcNAcylation plays a role in tumor recurrence of hepatocellular carcinoma following liver transplantation. Med. Oncol. 2012, 29, 985-993. [CrossRef] [PubMed]

90. Krzeslak, A.; Wojcik-Krowiranda, K.; Forma, E.; Bienkiewicz, A.; Brys, M. Expression of genes encoding

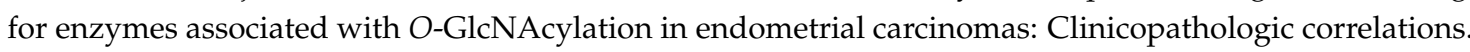
Ginekologia Polska 2012, 83, 22-26. [PubMed]

91. Kim, M.J.; Choi, M.Y.; Lee, D.H.; Roh, G.S.; Kim, H.J.; Kang, S.S.; Cho, G.J.; Kim, Y.S.; Choi, W.S. O-linked $\mathrm{N}$-acetylglucosamine transferase enhances secretory clusterin expression via liver $\mathrm{X}$ receptors and sterol response element binding protein regulation in cervical cancer. Oncotarget 2018, 9, 4625-4636. [CrossRef] [PubMed]

92. Lynch, T.P.; Ferrer, C.M.; Jackson, S.R.; Shahriari, K.S.; Vosseller, K.; Reginato, M.J. Critical role of O-Linked beta- $N$-acetylglucosamine transferase in prostate cancer invasion, angiogenesis, and metastasis. J. Biol. Chem. 2012, 287, 11070-11081. [CrossRef] [PubMed]

93. Ma, Z.; Vocadlo, D.J.; Vosseller, K. Hyper-O-GlcNAcylation is anti-apoptotic and maintains constitutive NF-kappaB activity in pancreatic cancer cells. J. Biol. Chem. 2013, 288, 15121-15130. [CrossRef] [PubMed]

94. Zhang, X.; Ma, L.; Qi, J.; Shan, H.; Yu, W.; Gu, Y. MAPK/ERK signaling pathway-induced hyper-OGlcNAcylation enhances cancer malignancy. Mol. Cell. Biochem. 2015, 410, 101-110. [CrossRef] [PubMed]

95. Sodi, V.L.; Khaku, S.; Krutilina, R.; Schwab, L.P.; Vocadlo, D.J.; Seagroves, T.N.; Reginato, M.J. mTOR/MYC Axis Regulates O-GlcNAc Transferase Expression and O-GlcNAcylation in Breast Cancer. Mol. Cancer Res. MCR 2015, 13, 923-933. [CrossRef] [PubMed]

96. Clark, P.M.; Dweck, J.F.; Mason, D.E.; Hart, C.R.; Buck, S.B.; Peters, E.C.; Agnew, B.J.; Hsieh-Wilson, L.C. Direct in-gel fluorescence detection and cellular imaging of O-GlcNAc-modified proteins. J. Am. Chem. Soc. 2008, 130, 11576-11577. [CrossRef] [PubMed] 
97. Hahne, H.; Sobotzki, N.; Nyberg, T.; Helm, D.; Borodkin, V.S.; van Aalten, D.M.; Agnew, B.; Kuster, B. Proteome wide purification and identification of $O$-GlcNAc-modified proteins using click chemistry and mass spectrometry. J. Proteome Res. 2013, 12, 927-936. [CrossRef] [PubMed]

98. Nandi, A.; Sprung, R.; Barma, D.K.; Zhao, Y.; Kim, S.C.; Falck, J.R.; Zhao, Y. Global identification of O-GlcNAc-modified proteins. Anal. Chem. 2006, 78, 452-458. [CrossRef] [PubMed]

99. Park, J.; Han, D.; Kim, K.; Kang, Y.; Kim, Y. O-GlcNAcylation disrupts glyceraldehyde-3-phosphate dehydrogenase homo-tetramer formation and mediates its nuclear translocation. Biochim. Biophys. Acta 2009, 1794, 254-262. [CrossRef] [PubMed]

100. Sirover, M.A. New nuclear functions of the glycolytic protein, glyceraldehyde-3-phosphate dehydrogenase, in mammalian cells. J. Cell. Biochem. 2005, 95, 45-52. [CrossRef] [PubMed]

101. Yi, W.; Clark, P.M.; Mason, D.E.; Keenan, M.C.; Hill, C.; Goddard, W.A., 3rd; Peters, E.C.; Driggers, E.M.; Hsieh-Wilson, L.C. Phosphofructokinase 1 glycosylation regulates cell growth and metabolism. Science 2012, 337, 975-980. [CrossRef] [PubMed]

102. Rao, X.; Duan, X.; Mao, W.; Li, X.; Li, Z.; Li, Q.; Zheng, Z.; Xu, H.; Chen, M.; Wang, P.G.; et al. O-GlcNAcylation of G6PD promotes the pentose phosphate pathway and tumor growth. Nat. Commun. 2015, 6, 8468. [CrossRef] [PubMed]

103. Christofk, H.R.; Vander Heiden, M.G.; Harris, M.H.; Ramanathan, A.; Gerszten, R.E.; Wei, R.; Fleming, M.D.; Schreiber, S.L.; Cantley, L.C. The M2 splice isoform of pyruvate kinase is important for cancer metabolism and tumour growth. Nature 2008, 452, 230-233. [CrossRef] [PubMed]

104. Chaiyawat, P.; Chokchaichamnankit, D.; Lirdprapamongkol, K.; Srisomsap, C.; Svasti, J.; Champattanachai, V. Alteration of $O$-GlcNAcylation affects serine phosphorylation and regulates gene expression and activity of pyruvate kinase M2 in colorectal cancer cells. Oncol. Rep. 2015, 34, 1933-1942. [CrossRef] [PubMed]

105. Wang, Y.; Liu, J.; Jin, X.; Zhang, D.; Li, D.; Hao, F.; Feng, Y.; Gu, S.; Meng, F.; Tian, M.; et al. O-GlcNAcylation destabilizes the active tetrameric PKM2 to promote the Warburg effect. Proc. Natl. Acad. Sci. USA 2017, 114, 13732-13737. [CrossRef] [PubMed]

106. Anastasiou, D.; Yu, Y.; Israelsen, W.J.; Jiang, J.K.; Boxer, M.B.; Hong, B.S.; Tempel, W.; Dimov, S.; Shen, M.; Jha, A.; et al. Pyruvate kinase M2 activators promote tetramer formation and suppress tumorigenesis. Nat. Chem. Biol. 2012, 8, 839-847. [CrossRef] [PubMed]

107. Yang, W.; Zheng, Y.; Xia, Y.; Ji, H.; Chen, X.; Guo, F.; Lyssiotis, C.A.; Aldape, K.; Cantley, L.C.; Lu, Z. ERK1/2-dependent phosphorylation and nuclear translocation of PKM2 promotes the Warburg effect. Nat. Cell Biol. 2012, 14, 1295-1304. [CrossRef] [PubMed]

108. Cai, P.; Jin, X.; Zhu, H.; Zhu, S.; Wang, L.; Jin, J. OGT-mediated O-GlcNAcylation on GLDC promotes metastasis in cervical cancer. Oncotarget 2018. [CrossRef]

109. Maury, J.J.; Chan, K.K.; Zheng, L.; Bardor, M.; Choo, A.B. Excess of O-linked N-acetylglucosamine modifies human pluripotent stem cell differentiation. Stem Cell Res. 2013, 11, 926-937. [CrossRef] [PubMed]

110. Kim, H.M.; Jung, W.H.; Koo, J.S. Site-specific metabolic phenotypes in metastatic breast cancer. J. Transl. Med. 2014, 12, 354. [CrossRef] [PubMed]

111. Kim, Y.H.; Jung, W.H.; Koo, J.S. Expression of metabolism-related proteins in invasive lobular carcinoma: Comparison to invasive ductal carcinoma. Tumour Biol. 2014, 35, 10381-10393. [CrossRef] [PubMed]

112. Kwon, J.E.; Kim, D.H.; Jung, W.H.; Koo, J.S. Expression of serine and glycine-related enzymes in phyllodes tumor. Neoplasma 2014, 61, 566-578. [CrossRef] [PubMed]

113. Noh, S.; Kim, D.H.; Jung, W.H.; Koo, J.S. Expression levels of serine/glycine metabolism-related proteins in triple negative breast cancer tissues. Tumour Biol. 2014, 35, 4457-4468. [CrossRef] [PubMed]

114. Sun, W.Y.; Kim, H.M.; Jung, W.H.; Koo, J.S. Expression of serine/glycine metabolism-related proteins is different according to the thyroid cancer subtype. J. Transl. Med. 2016, 14, 168. [CrossRef] [PubMed]

115. Zhang, W.C.; Shyh-Chang, N.; Yang, H.; Rai, A.; Umashankar, S.; Ma, S.; Soh, B.S.; Sun, L.L.; Tai, B.C.; Nga, M.E.; et al. Glycine decarboxylase activity drives non-small cell lung cancer tumor-initiating cells and tumorigenesis. Cell 2012, 148, 259-272. [CrossRef] [PubMed]

116. Araujo, L.; Khim, P.; Mkhikian, H.; Mortales, C.L.; Demetriou, M. Glycolysis and glutaminolysis cooperatively control T cell function by limiting metabolite supply to N-glycosylation. eLife 2017, 6, e21330. [CrossRef] [PubMed] 
117. Baldini, S.F.; Wavelet, C.; Hainault, I.; Guinez, C.; Lefebvre, T. The Nutrient-Dependent O-GlcNAc Modification Controls the Expression of Liver Fatty Acid Synthase. J. Mol. Biol. 2016, 428, 3295-3304. [CrossRef] [PubMed]

118. Graner, E.; Tang, D.; Rossi, S.; Baron, A.; Migita, T.; Weinstein, L.J.; Lechpammer, M.; Huesken, D.; Zimmermann, J.; Signoretti, S.; et al. The isopeptidase USP2a regulates the stability of fatty acid synthase in prostate cancer. Cancer Cell 2004, 5, 253-261. [CrossRef]

119. Groves, J.A.; Maduka, A.O.; O’Meally, R.N.; Cole, R.N.; Zachara, N.E. Fatty acid synthase inhibits the O-GlcNAcase during oxidative stress. J. Biol. Chem. 2017, 292, 6493-6511. [CrossRef] [PubMed]

120. Ma, J.; Liu, T.; Wei, A.C.; Banerjee, P.; O’Rourke, B.; Hart, G.W. O-GlcNAcomic Profiling Identifies Widespread O-Linked beta- $\mathrm{N}$-Acetylglucosamine Modification (O-GlcNAcylation) in Oxidative Phosphorylation System Regulating Cardiac Mitochondrial Function. J. Biol. Chem. 2015, 290, 29141-29153. [CrossRef] [PubMed]

121. Sacoman, J.L.; Dagda, R.Y.; Burnham-Marusich, A.R.; Dagda, R.K.; Berninsone, P.M. Mitochondrial O-GlcNAc Transferase (mOGT) Regulates Mitochondrial Structure, Function, and Survival in HeLa Cells. J. Biol. Chem. 2017, 292, 4499-4518. [CrossRef] [PubMed]

122. Tan, E.P.; Villar, M.T.; Lezi, E.; Lu, J.; Selfridge, J.E.; Artigues, A.; Swerdlow, R.H.; Slawson, C. Altering $\mathrm{O}$-linked beta- $\mathrm{N}$-acetylglucosamine cycling disrupts mitochondrial function. J. Biol. Chem. 2014, 289, 14719-14730. [CrossRef] [PubMed]

123. Shi, H.; Munk, A.; Nielsen, T.S.; Daughtry, M.R.; Larsson, L.; Li, S.; Hoyer, K.F.; Geisler, H.W.; Sulek, K.; Kjobsted, R.; et al. Skeletal muscle O-GlcNAc transferase is important for muscle energy homeostasis and whole-body insulin sensitivity. Mol. Metab. 2018, 11, 160-177. [CrossRef] [PubMed]

124. Cha, M.Y.; Cho, H.J.; Kim, C.; Jung, Y.O.; Kang, M.J.; Murray, M.E.; Hong, H.S.; Choi, Y.J.; Choi, H.; Kim, D.K.; et al. Mitochondrial ATP synthase activity is impaired by suppressed O-GlcNAcylation in Alzheimer's disease. Hum. Mol. Genet. 2015, 24, 6492-6504. [CrossRef] [PubMed]

125. Gawlowski, T.; Suarez, J.; Scott, B.; Torres-Gonzalez, M.; Wang, H.; Schwappacher, R.; Han, X.; Yates, J.R., 3rd; Hoshijima, M.; Dillmann, W. Modulation of dynamin-related protein 1 (DRP1) function by increased O-linked-beta- $N$-acetylglucosamine modification (O-GlcNAc) in cardiac myocytes. J. Biol. Chem. 2012, 287, 30024-30034. [CrossRef] [PubMed]

126. Hu, Y.; Suarez, J.; Fricovsky, E.; Wang, H.; Scott, B.T.; Trauger, S.A.; Han, W.; Hu, Y.; Oyeleye, M.O.; Dillmann, W.H. Increased enzymatic $O$-GlcNAcylation of mitochondrial proteins impairs mitochondrial function in cardiac myocytes exposed to high glucose. J. Biol. Chem. 2009, 284, 547-555. [CrossRef] [PubMed]

127. Makino, A.; Suarez, J.; Gawlowski, T.; Han, W.; Wang, H.; Scott, B.T.; Dillmann, W.H. Regulation of mitochondrial morphology and function by O-GlcNAcylation in neonatal cardiac myocytes. Am. J. Physiol. Regul. Integr. Comp. Physiol. 2011, 300, R1296-R1302. [CrossRef] [PubMed]

128. Zong, W.X.; Rabinowitz, J.D.; White, E. Mitochondria and Cancer. Mol. Cell 2016, 61, 667-676. [CrossRef] [PubMed]

129. Baracca, A.; Chiaradonna, F.; Sgarbi, G.; Solaini, G.; Alberghina, L.; Lenaz, G. Mitochondrial Complex I decrease is responsible for bioenergetic dysfunction in K-ras transformed cells. Biochim. Biophys. Acta 2010, 1797, 314-323. [CrossRef] [PubMed]

130. Chiaradonna, F.; Gaglio, D.; Vanoni, M.; Alberghina, L. Expression of transforming K-Ras oncogene affects mitochondrial function and morphology in mouse fibroblasts. Biochim. Biophys. Acta 2006, 1757, 1338-1356. [CrossRef] [PubMed]

131. Eales, K.L.; Hollinshead, K.E.; Tennant, D.A. Hypoxia and metabolic adaptation of cancer cells. Oncogenesis 2016, 5, e190. [CrossRef] [PubMed]

132. Fukuda, R.; Zhang, H.; Kim, J.W.; Shimoda, L.; Dang, C.V.; Semenza, G.L. HIF-1 regulates cytochrome oxidase subunits to optimize efficiency of respiration in hypoxic cells. Cell 2007, 129, 111-122. [CrossRef] [PubMed]

133. Yang, D.; Wang, M.T.; Tang, Y.; Chen, Y.; Jiang, H.; Jones, T.T.; Rao, K.; Brewer, G.J.; Singh, K.K.; Nie, D. Impairment of mitochondrial respiration in mouse fibroblasts by oncogenic H-RAS(Q61L). Cancer Biol. Ther. 2010, 9, 122-133. [CrossRef] [PubMed]

134. Hardie, D.G.; Alessi, D.R. LKB1 and AMPK and the cancer-metabolism link-Ten years after. BMC Biol. 2013, 11, 36. [CrossRef] [PubMed] 
135. Faubert, B.; Boily, G.; Izreig, S.; Griss, T.; Samborska, B.; Dong, Z.; Dupuy, F.; Chambers, C.; Fuerth, B.J.; Viollet, B.; et al. AMPK is a negative regulator of the Warburg effect and suppresses tumor growth in vivo. Cell Metab. 2013, 17, 113-124. [CrossRef] [PubMed]

136. Shackelford, D.B.; Vasquez, D.S.; Corbeil, J.; Wu, S.; Leblanc, M.; Wu, C.L.; Vera, D.R.; Shaw, R.J. mTOR and HIF-1alpha-mediated tumor metabolism in an LKB1 mouse model of Peutz-Jeghers syndrome. Proc. Natl. Acad. Sci. USA 2009, 106, 11137-11142. [CrossRef] [PubMed]

137. Thomas, G.V.; Tran, C.; Mellinghoff, I.K.; Welsbie, D.S.; Chan, E.; Fueger, B.; Czernin, J.; Sawyers, C.L. Hypoxia-inducible factor determines sensitivity to inhibitors of mTOR in kidney cancer. Nat. Med. 2006, 12, 122-127. [CrossRef] [PubMed]

138. Gerhart-Hines, Z.; Dominy, J.E., Jr.; Blattler, S.M.; Jedrychowski, M.P.; Banks, A.S.; Lim, J.H.; Chim, H.; Gygi, S.P.; Puigserver, P. The cAMP/PKA pathway rapidly activates SIRT1 to promote fatty acid oxidation independently of changes in NAD(+). Mol. Cell 2011, 44, 851-863. [CrossRef] [PubMed]

139. Herzig, S.; Long, F.; Jhala, U.S.; Hedrick, S.; Quinn, R.; Bauer, A.; Rudolph, D.; Schutz, G.; Yoon, C.; Puigserver, P.; et al. CREB regulates hepatic gluconeogenesis through the coactivator PGC-1. Nature 2001, 413, 179-183. [CrossRef] [PubMed]

140. Lim, J.H.; Gerhart-Hines, Z.; Dominy, J.E.; Lee, Y.; Kim, S.; Tabata, M.; Xiang, Y.K.; Puigserver, P. Oleic acid stimulates complete oxidation of fatty acids through protein kinase A-dependent activation of SIRT1-PGC1alpha complex. J. Biol. Chem. 2013, 288, 7117-7126. [CrossRef] [PubMed]

141. Palorini, R.; De Rasmo, D.; Gaviraghi, M.; Sala Danna, L.; Signorile, A.; Cirulli, C.; Chiaradonna, F.; Alberghina, L.; Papa, S. Oncogenic K-ras expression is associated with derangement of the cAMP/PKA pathway and forskolin-reversible alterations of mitochondrial dynamics and respiration. Oncogene 2013, 32, 352-362. [CrossRef] [PubMed]

142. Eguchi, S.; Oshiro, N.; Miyamoto, T.; Yoshino, K.; Okamoto, S.; Ono, T.; Kikkawa, U.; Yonezawa, K. AMP-activated protein kinase phosphorylates glutamine: Fructose-6-phosphate amidotransferase 1 at Ser243 to modulate its enzymatic activity. Genes Cells 2009, 14, 179-189. [CrossRef] [PubMed]

143. Zibrova, D.; Vandermoere, F.; Goransson, O.; Peggie, M.; Marino, K.V.; Knierim, A.; Spengler, K.; Weigert, C.; Viollet, B.; Morrice, N.A.; et al. GFAT1 phosphorylation by AMPK promotes VEGF-induced angiogenesis. Biochem. J. 2017, 474, 983-1001. [CrossRef] [PubMed]

144. Bullen, J.W.; Balsbaugh, J.L.; Chanda, D.; Shabanowitz, J.; Hunt, D.F.; Neumann, D.; Hart, G.W. Cross-talk between two essential nutrient-sensitive enzymes: $O$-GlcNAc transferase (OGT) and AMP-activated protein kinase (AMPK). J. Biol. Chem. 2014, 289, 10592-10606. [CrossRef] [PubMed]

145. Ishimura, E.; Nakagawa, T.; Moriwaki, K.; Hirano, S.; Matsumori, Y.; Asahi, M. Augmented O-GlcNAcylation of AMP-activated kinase promotes the proliferation of LoVo cells, a colon cancer cell line. Cancer Sci. 2017, 108, 2373-2382. [CrossRef] [PubMed]

146. Xu, Q.; Yang, C.; Du, Y.; Chen, Y.; Liu, H.; Deng, M.; Zhang, H.; Zhang, L.; Liu, T.; Liu, Q.; et al. AMPK regulates histone H2B O-GlcNAcylation. Nucleic Acids Res. 2014, 42, 5594-5604. [CrossRef] [PubMed]

147. Hu, Y.; Riesland, L.; Paterson, A.J.; Kudlow, J.E. Phosphorylation of mouse glutamine-fructose-6-phosphate amidotransferase 2 (GFAT2) by cAMP-dependent protein kinase increases the enzyme activity. J. Biol. Chem. 2004, 279, 29988-29993. [CrossRef] [PubMed]

148. Li, Y.; Roux, C.; Lazereg, S.; LeCaer, J.P.; Laprevote, O.; Badet, B.; Badet-Denisot, M.A. Identification of a novel serine phosphorylation site in human glutamine:fructose-6-phosphate amidotransferase isoform 1. Biochemistry 2007, 46, 13163-13169. [CrossRef] [PubMed]

149. Jin, N.; Ma, D.; Gu, J.; Shi, J.; Xu, X.; Iqbal, K.; Gong, C.X.; Liu, F.; Chu, D. O-GlcNAcylation modulates PKA-CREB signaling in a manner specific to PKA catalytic subunit isoforms. Biochem. Biophys. Res. Commun. 2018, 497, 194-199. [CrossRef] [PubMed]

150. Xie, S.; Jin, N.; Gu, J.; Shi, J.; Sun, J.; Chu, D.; Zhang, L.; Dai, C.L.; Gu, J.H.; Gong, C.X.; et al. O-GlcNAcylation of protein kinase A catalytic subunits enhances its activity: A mechanism linked to learning and memory deficits in Alzheimer's disease. Aging Cell 2016, 15, 455-464. [CrossRef] [PubMed]

151. Djouder, N.; Tuerk, R.D.; Suter, M.; Salvioni, P.; Thali, R.F.; Scholz, R.; Vaahtomeri, K.; Auchli, Y.; Rechsteiner, H.; Brunisholz, R.A.; et al. PKA phosphorylates and inactivates AMPKalpha to promote efficient lipolysis. EMBO J. 2010, 29, 469-481. [CrossRef] [PubMed] 
152. Ferretti, A.C.; Tonucci, F.M.; Hidalgo, F.; Almada, E.; Larocca, M.C.; Favre, C. AMPK and PKA interaction in the regulation of survival of liver cancer cells subjected to glucose starvation. Oncotarget 2016, 7, 17815-17828. [CrossRef] [PubMed]

153. Chou, T.Y.; Dang, C.V.; Hart, G.W. Glycosylation of the c-Myc transactivation domain. Proc. Natl. Acad. Sci. USA 1995, 92, 4417-4421. [CrossRef] [PubMed]

154. Gregory, M.A.; Qi, Y.; Hann, S.R. Phosphorylation by glycogen synthase kinase-3 controls c-myc proteolysis and subnuclear localization. J. Biol. Chem. 2003, 278, 51606-51612. [CrossRef] [PubMed]

155. Bello-Fernandez, C.; Packham, G.; Cleveland, J.L. The ornithine decarboxylase gene is a transcriptional target of c-Myc. Proc. Natl. Acad. Sci. USA 1993, 90, 7804-7808. [CrossRef] [PubMed]

156. Miltenberger, R.J.; Sukow, K.A.; Farnham, P.J. An E-box-mediated increase in cad transcription at the G1/S-phase boundary is suppressed by inhibitory c-Myc mutants. Mol. Cell. Biol. 1995, 15, 2527-2535. [CrossRef] [PubMed]

157. Mai, S.; Jalava, A. c-Myc binds to $5^{\prime}$ flanking sequence motifs of the dihydrofolate reductase gene in cellular extracts: Role in proliferation. Nucleic Acids Res. 1994, 22, 2264-2273. [CrossRef] [PubMed]

158. Pusch, O.; Soucek, T.; Hengstschlager-Ottnad, E.; Bernaschek, G.; Hengstschlager, M. Cellular targets for activation by c-Myc include the DNA metabolism enzyme thymidine kinase. DNA Cell Biol. 1997, 16, 737-747. [PubMed]

159. Dang, C.V.; Le, A.; Gao, P. MYC-induced cancer cell energy metabolism and therapeutic opportunities. Clin. Cancer Res. 2009, 15, 6479-6483. [CrossRef] [PubMed]

160. Shim, H.; Dolde, C.; Lewis, B.C.; Wu, C.S.; Dang, G.; Jungmann, R.A.; Dalla-Favera, R.; Dang, C.V. c-Myc transactivation of LDH-A: Implications for tumor metabolism and growth. Proc. Natl. Acad. Sci. USA 1997, 94, 6658-6663. [CrossRef] [PubMed]

161. Gao, P.; Tchernyshyov, I.; Chang, T.C.; Lee, Y.S.; Kita, K.; Ochi, T.; Zeller, K.I.; De Marzo, A.M.; Van Eyk, J.E.; Mendell, J.T.; et al. c-Myc suppression of miR-23a/b enhances mitochondrial glutaminase expression and glutamine metabolism. Nature 2009, 458, 762-775. [CrossRef] [PubMed]

162. Moreadith, R.W.; Lehninger, A.L. The pathways of glutamate and glutamine oxidation by tumor cell mitochondria. Role of mitochondrial NAD(P)+-dependent malic enzyme. J. Biol. Chem. 1984, 259, 6215-6221. [PubMed]

163. Luanpitpong, S.; Angsutararux, P.; Samart, P.; Chanthra, N.; Chanvorachote, P.; Issaragrisil, S. Hyper-OGlcNAcylation induces cisplatin resistance via regulation of p53 and c-Myc in human lung carcinoma. Sci. Rep. 2017, 7, 10607. [CrossRef] [PubMed]

164. Tan, Z.; Luo, X.; Xiao, L.; Tang, M.; Bode, A.M.; Dong, Z.; Cao, Y. The Role of PGC1alpha in Cancer Metabolism and its Therapeutic Implications. Mol. Cancer Ther. 2016, 15, 774-782. [CrossRef] [PubMed]

165. Ruan, H.B.; Han, X.; Li, M.D.; Singh, J.P.; Qian, K.; Azarhoush, S.; Zhao, L.; Bennett, A.M.; Samuel, V.T.; $\mathrm{Wu}$, J.; et al. O-GlcNAc transferase/host cell factor $\mathrm{C} 1$ complex regulates gluconeogenesis by modulating PGC-1alpha stability. Cell Metab. 2012, 16, 226-237. [CrossRef] [PubMed]

166. Housley, M.P.; Rodgers, J.T.; Udeshi, N.D.; Kelly, T.J.; Shabanowitz, J.; Hunt, D.F.; Puigserver, P.; Hart, G.W. O-GlcNAc regulates FoxO activation in response to glucose. J. Biol. Chem. 2008, 283, 16283-16292. [CrossRef] [PubMed]

167. Ohashi, N.; Morino, K.; Ida, S.; Sekine, O.; Lemecha, M.; Kume, S.; Park, S.Y.; Choi, C.S.; Ugi, S.; Maegawa, H. Pivotal Role of $O$-GlcNAc Modification in Cold-Induced Thermogenesis by Brown Adipose Tissue Through Mitochondrial Biogenesis. Diabetes 2017, 66, 2351-2362. [CrossRef] [PubMed]

168. Wu, Z.; Puigserver, P.; Andersson, U.; Zhang, C.; Adelmant, G.; Mootha, V.; Troy, A.; Cinti, S.; Lowell, B.; Scarpulla, R.C.; et al. Mechanisms controlling mitochondrial biogenesis and respiration through the thermogenic coactivator PGC-1. Cell 1999, 98, 115-124. [CrossRef]

169. Latorre, P.; Varona, L.; Burgos, C.; Carrodeguas, J.A.; Lopez-Buesa, P. O-GlcNAcylation mediates the control of cytosolic phosphoenolpyruvate carboxykinase activity via Pgc1alpha. PLoS ONE 2017, 12, e0179988. [CrossRef] [PubMed]

170. LeBleu, V.S.; O'Connell, J.T.; Gonzalez Herrera, K.N.; Wikman, H.; Pantel, K.; Haigis, M.C.; de Carvalho, F.M.; Damascena, A.; Domingos Chinen, L.T.; Rocha, R.M.; et al. PGC-1alpha mediates mitochondrial biogenesis and oxidative phosphorylation in cancer cells to promote metastasis. Nat. Cell Biol. 2014, 16, 992-1003. [CrossRef] [PubMed] 
171. Carracedo, A.; Weiss, D.; Leliaert, A.K.; Bhasin, M.; de Boer, V.C.; Laurent, G.; Adams, A.C.; Sundvall, M.; Song, S.J.; Ito, K.; et al. A metabolic prosurvival role for PML in breast cancer. J. Clin. Investig. 2012, 122, 3088-3100. [CrossRef] [PubMed]

172. Shiota, M.; Yokomizo, A.; Tada, Y.; Inokuchi, J.; Tatsugami, K.; Kuroiwa, K.; Uchiumi, T.; Fujimoto, N.; Seki, N.; Naito, S. Peroxisome proliferator-activated receptor gamma coactivator-1alpha interacts with the androgen receptor (AR) and promotes prostate cancer cell growth by activating the AR. Mol. Endocrinol. 2010, 24, 114-127. [CrossRef] [PubMed]

173. Bhalla, K.; Hwang, B.J.; Dewi, R.E.; Ou, L.; Twaddel, W.; Fang, H.B.; Vafai, S.B.; Vazquez, F.; Puigserver, P.; Boros, L.; et al. PGC1alpha promotes tumor growth by inducing gene expression programs supporting lipogenesis. Cancer Res. 2011, 71, 6888-6898. [CrossRef] [PubMed]

174. McGuirk, S.; Gravel, S.P.; Deblois, G.; Papadopoli, D.J.; Faubert, B.; Wegner, A.; Hiller, K.; Avizonis, D.; Akavia, U.D.; Jones, R.G.; et al. PGC-1alpha supports glutamine metabolism in breast cancer. Cancer Metab. 2013, 1, 22. [CrossRef] [PubMed]

175. Vousden, K.H. p53: Death star. Cell 2000, 103, 691-694. [CrossRef]

176. Bode, A.M.; Dong, Z. Post-translational modification of p53 in tumorigenesis. Nat. Rev. Cancer 2004, 4, 793-805. [CrossRef] [PubMed]

177. De Queiroz, R.M.; Madan, R.; Chien, J.; Dias, W.B.; Slawson, C. Changes in O-Linked N-Acetylglucosamine (O-GlcNAc) Homeostasis Activate the p53 Pathway in Ovarian Cancer Cells. J. Biol. Chem. 2016, 291, 18897-18914. [CrossRef] [PubMed]

178. Yang, W.H.; Kim, J.E.; Nam, H.W.; Ju, J.W.; Kim, H.S.; Kim, Y.S.; Cho, J.W. Modification of p53 with O-linked $\mathrm{N}$-acetylglucosamine regulates p53 activity and stability. Nat. Cell Biol. 2006, 8, 1074-1083. [CrossRef] [PubMed]

179. Maddocks, O.D.; Vousden, K.H. Metabolic regulation by p53. J. Mol. Med. 2011, 89, 237-245. [CrossRef] [PubMed]

180. Fardini, Y.; Perez-Cervera, Y.; Camoin, L.; Pagesy, P.; Lefebvre, T.; Issad, T. Regulatory O-GlcNAcylation sites on FoxO1 are yet to be identified. Biochem. Biophys. Res. Commun. 2015, 462, 151-158. [CrossRef] [PubMed]

181. Kuo, M.; Zilberfarb, V.; Gangneux, N.; Christeff, N.; Issad, T. O-GlcNAc modification of FoxO1 increases its transcriptional activity: A role in the glucotoxicity phenomenon? Biochimie 2008, 90, 679-685. [CrossRef] [PubMed]

182. Greer, E.L.; Brunet, A. FOXO transcription factors at the interface between longevity and tumor suppression. Oncogene 2005, 24, 7410-7425. [CrossRef] [PubMed]

183. Wilhelm, K.; Happel, K.; Eelen, G.; Schoors, S.; Oellerich, M.F.; Lim, R.; Zimmermann, B.; Aspalter, I.M.; Franco, C.A.; Boettger, T.; et al. FOXO1 couples metabolic activity and growth state in the vascular endothelium. Nature 2016, 529, 216-220. [CrossRef] [PubMed]

184. Menendez, J.A.; Lupu, R. Fatty acid synthase and the lipogenic phenotype in cancer pathogenesis. Nat. Rev. Cancer 2007, 7, 763-777. [CrossRef] [PubMed]

185. Deng, X.; Zhang, W.; InSug, O.; Williams, J.B.; Dong, Q.; Park, E.A.; Raghow, R.; Unterman, T.G.; Elam, M.B. FoxO1 inhibits sterol regulatory element-binding protein-1c (SREBP-1c) gene expression via transcription factors Sp1 and SREBP-1c. J. Biol. Chem. 2012, 287, 20132-20143. [CrossRef] [PubMed]

186. Muller, P.A.; Vousden, K.H. p53 mutations in cancer. Nat. Cell Biol. 2013, 15, 2-8. [CrossRef] [PubMed]

187. Morin, R.D.; Mendez-Lago, M.; Mungall, A.J.; Goya, R.; Mungall, K.L.; Corbett, R.D.; Johnson, N.A.; Severson, T.M.; Chiu, R.; Field, M.; et al. Frequent mutation of histone-modifying genes in non-Hodgkin lymphoma. Nature 2011, 476, 298-303. [CrossRef] [PubMed]

188. Wang, Y.; Zhou, Y.; Graves, D.T. FOXO transcription factors: Their clinical significance and regulation. BioMed Res. Int. 2014, 2014, 925350. [CrossRef] [PubMed]

189. Yang, W.H.; Park, S.Y.; Nam, H.W.; Kim, D.H.; Kang, J.G.; Kang, E.S.; Kim, Y.S.; Lee, H.C.; Kim, K.S.; Cho, J.W. NFkappaB activation is associated with its O-GlcNAcylation state under hyperglycemic conditions. Proc. Natl. Acad. Sci. USA 2008, 105, 17345-17350. [CrossRef] [PubMed]

190. Mauro, C.; Leow, S.C.; Anso, E.; Rocha, S.; Thotakura, A.K.; Tornatore, L.; Moretti, M.; De Smaele, E.; Beg, A.A.; Tergaonkar, V.; et al. NF-kappaB controls energy homeostasis and metabolic adaptation by upregulating mitochondrial respiration. Nat. Cell Biol. 2011, 13, 1272-1279. [CrossRef] [PubMed]

191. Tornatore, L.; Thotakura, A.K.; Bennett, J.; Moretti, M.; Franzoso, G. The nuclear factor kappa B signaling pathway: Integrating metabolism with inflammation. Trends Cell Biol. 2012, 22, 557-566. [CrossRef] [PubMed] 
192. Kawauchi, K.; Araki, K.; Tobiume, K.; Tanaka, N. p53 regulates glucose metabolism through an IKK-NF-kappaB pathway and inhibits cell transformation. Nat. Cell Biol. 2008, 10, 611-618. [CrossRef] [PubMed]

193. Dentin, R.; Pegorier, J.P.; Benhamed, F.; Foufelle, F.; Ferre, P.; Fauveau, V.; Magnuson, M.A.; Girard, J.; Postic, C. Hepatic glucokinase is required for the synergistic action of ChREBP and SREBP-1c on glycolytic and lipogenic gene expression. J. Biol. Chem. 2004, 279, 20314-20326. [CrossRef] [PubMed]

194. Ishii, S.; Iizuka, K.; Miller, B.C.; Uyeda, K. Carbohydrate response element binding protein directly promotes lipogenic enzyme gene transcription. Proc. Natl. Acad. Sci. USA 2004, 101, 15597-15602. [CrossRef] [PubMed]

195. Wang, H.; Wollheim, C.B. ChREBP rather than USF2 regulates glucose stimulation of endogenous L-pyruvate kinase expression in insulin-secreting cells. J. Biol. Chem. 2002, 277, 32746-32752. [CrossRef] [PubMed]

196. Da Silva Xavier, G.; Rutter, G.A.; Diraison, F.; Andreolas, C.; Leclerc, I. ChREBP binding to fatty acid synthase and L-type pyruvate kinase genes is stimulated by glucose in pancreatic beta-cells. J. Lipid Res. 2006, 47, 2482-2491. [CrossRef] [PubMed]

197. Guinez, C.; Filhoulaud, G.; Rayah-Benhamed, F.; Marmier, S.; Dubuquoy, C.; Dentin, R.; Moldes, M.; Burnol, A.F.; Yang, X.; Lefebvre, T.; et al. O-GlcNAcylation increases ChREBP protein content and transcriptional activity in the liver. Diabetes 2011, 60, 1399-1413. [CrossRef] [PubMed]

198. Sakiyama, H.; Fujiwara, N.; Noguchi, T.; Eguchi, H.; Yoshihara, D.; Uyeda, K.; Suzuki, K. The role of O-linked GlcNAc modification on the glucose response of ChREBP. Biochem. Biophys. Res. Commun. 2010, 402, 784-789. [CrossRef] [PubMed]

199. Iizuka, K. The transcription factor carbohydrate-response element-binding protein (ChREBP): A possible link between metabolic disease and cancer. Biochim. Biophys. Acta 2017, 1863, 474-485. [CrossRef] [PubMed]

200. Tong, X.; Zhao, F.; Mancuso, A.; Gruber, J.J.; Thompson, C.B. The glucose-responsive transcription factor ChREBP contributes to glucose-dependent anabolic synthesis and cell proliferation. Proc. Natl. Acad. Sci. USA 2009, 106, 21660-21665. [CrossRef] [PubMed]

201. Airley, R.E.; McHugh, P.; Evans, A.R.; Harris, B.; Winchester, L.; Buffa, F.M.; Al-Tameemi, W.; Leek, R.; Harris, A.L. Role of carbohydrate response element-binding protein (ChREBP) in generating an aerobic metabolic phenotype and in breast cancer progression. Br. J. Cancer 2014, 110, 715-723. [CrossRef] [PubMed]

202. Banerjee, S.; Sangwan, V.; McGinn, O.; Chugh, R.; Dudeja, V.; Vickers, S.M.; Saluja, A.K. Triptolide-induced cell death in pancreatic cancer is mediated by O-GlcNAc modification of transcription factor Sp1. J. Biol. Chem. 2013, 288, 33927-33938. [CrossRef] [PubMed]

203. Safe, S.; Abdelrahim, M. Sp transcription factor family and its role in cancer. Eur. J. Cancer 2005, 41, $2438-2448$. [CrossRef] [PubMed]

204. Majumdar, G.; Wright, J.; Markowitz, P.; Martinez-Hernandez, A.; Raghow, R.; Solomon, S.S. Insulin stimulates and diabetes inhibits O-linked $N$-acetylglucosamine transferase and $O$-glycosylation of Sp1. Diabetes 2004, 53, 3184-3192. [CrossRef] [PubMed]

205. Issad, T.; Kuo, M. O-GlcNAc modification of transcription factors, glucose sensing and glucotoxicity. Trends Endocrinol. Metab. TEM 2008, 19, 380-389. [CrossRef] [PubMed]

206. Chung, S.S.; Kim, J.H.; Park, H.S.; Choi, H.H.; Lee, K.W.; Cho, Y.M.; Lee, H.K.; Park, K.S. Activation of PPARgamma negatively regulates O-GlcNAcylation of Sp1. Biochem. Biophys. Res. Commun. 2008, 372, 713-718. [CrossRef] [PubMed]

207. Roos, M.D.; Su, K.; Baker, J.R.; Kudlow, J.E. O glycosylation of an Sp1-derived peptide blocks known Sp1 protein interactions. Mol. Cell. Biol. 1997, 17, 6472-6480. [CrossRef] [PubMed]

208. Lim, K.; Chang, H.I. O-GlcNAc modification of Sp1 inhibits the functional interaction between Sp1 and Oct1. FEBS Lett. 2009, 583, 512-520. [CrossRef] [PubMed]

209. Lim, K.; Chang, H.I. Elevated O-linked $N$-acetylglucosamine correlated with reduced Sp1 cooperative DNA binding with its collaborating factors in vivo. Biosci. Biotechnol. Biochem. 2010, 74, 1668-1672. [CrossRef] [PubMed]

210. Lim, K.; Yoon, B.H.; Ha, C.H. O-Linked N-acetylglucosaminylation of Sp1 interferes with Sp1 activation of glycolytic genes. Biochem. Biophys. Res. Commun. 2015, 468, 349-353. [CrossRef] [PubMed]

211. Bhonagiri, P.; Pattar, G.R.; Habegger, K.M.; McCarthy, A.M.; Tackett, L.; Elmendorf, J.S. Evidence coupling increased hexosamine biosynthesis pathway activity to membrane cholesterol toxicity and cortical filamentous actin derangement contributing to cellular insulin resistance. Endocrinology 2011, 152, 3373-3384. [CrossRef] [PubMed] 
212. Habegger, K.M.; Penque, B.A.; Sealls, W.; Tackett, L.; Bell, L.N.; Blue, E.K.; Gallagher, P.J.; Sturek, M.; Alloosh, M.A.; Steinberg, H.O.; et al. Fat-induced membrane cholesterol accrual provokes cortical filamentous actin destabilisation and glucose transport dysfunction in skeletal muscle. Diabetologia 2012, 55, 457-467. [CrossRef] [PubMed]

213. Penque, B.A.; Hoggatt, A.M.; Herring, B.P.; Elmendorf, J.S. Hexosamine biosynthesis impairs insulin action via a cholesterolgenic response. Mol. Endocrinol. 2013, 27, 536-547. [CrossRef] [PubMed]

214. Brasse-Lagnel, C.; Fairand, A.; Lavoinne, A.; Husson, A. Glutamine stimulates argininosuccinate synthetase gene expression through cytosolic O-glycosylation of Sp1 in Caco-2 cells. J. Biol. Chem. 2003, 278, 52504-52510. [CrossRef] [PubMed]

215. Kremer, J.C.; Prudner, B.C.; Lange, S.E.S.; Bean, G.R.; Schultze, M.B.; Brashears, C.B.; Radyk, M.D.; Redlich, N.; Tzeng, S.C.; Kami, K.; et al. Arginine Deprivation Inhibits the Warburg Effect and Upregulates Glutamine Anaplerosis and Serine Biosynthesis in ASS1-Deficient Cancers. Cell Rep. 2017, 18, 991-1004. [CrossRef] [PubMed]

216. Lu, S.; Archer, M.C. Sp1 coordinately regulates de novo lipogenesis and proliferation in cancer cells. Int. J. Cancer 2010, 126, 416-425. [CrossRef] [PubMed]

217. Mashima, T.; Seimiya, H.; Tsuruo, T. De novo fatty-acid synthesis and related pathways as molecular targets for cancer therapy. Br. J. Cancer 2009, 100, 1369-1372. [CrossRef] [PubMed]

218. Koslowski, M.; Tureci, O.; Bell, C.; Krause, P.; Lehr, H.A.; Brunner, J.; Seitz, G.; Nestle, F.O.; Huber, C.; Sahin, U. Multiple splice variants of lactate dehydrogenase $C$ selectively expressed in human cancer. Cancer Res. 2002, 62, 6750-6755. [PubMed]

219. Tang, H.; Goldberg, E. Homo sapiens lactate dehydrogenase c (Ldhc) gene expression in cancer cells is regulated by transcription factor Sp1, CREB, and CpG island methylation. J. Androl. 2009, 30, 157-167. [CrossRef] [PubMed]

220. Shi, Q.; Le, X.; Abbruzzese, J.L.; Peng, Z.; Qian, C.N.; Tang, H.; Xiong, Q.; Wang, B.; Li, X.C.; Xie, K. Constitutive Sp1 activity is essential for differential constitutive expression of vascular endothelial growth factor in human pancreatic adenocarcinoma. Cancer Res. 2001, 61, 4143-4154. [PubMed]

221. Wang, L.; Wei, D.; Huang, S.; Peng, Z.; Le, X.; Wu, T.T.; Yao, J.; Ajani, J.; Xie, K. Transcription factor Sp1 expression is a significant predictor of survival in human gastric cancer. Clin. Cancer Res. 2003, 9, 6371-6380. [PubMed]

222. Kumar, A.P.; Butler, A.P. Serum responsive gene expression mediated by Sp1. Biochem. Biophys. Res. Commun. 1998, 252, 517-523. [CrossRef] [PubMed]

223. Buse, M.G. Hexosamines, insulin resistance, and the complications of diabetes: Current status. Am. J. Physiol. Endocrinol. Metab. 2006, 290, E1-E8. [CrossRef] [PubMed]

224. Yuzwa, S.A.; Vocadlo, D.J. O-GlcNAc and neurodegeneration: Biochemical mechanisms and potential roles in Alzheimer's disease and beyond. Chem. Soc. Rev. 2014, 43, 6839-6858. [CrossRef] [PubMed]

225. Denzel, M.S.; Storm, N.J.; Gutschmidt, A.; Baddi, R.; Hinze, Y.; Jarosch, E.; Sommer, T.; Hoppe, T.; Antebi, A. Hexosamine pathway metabolites enhance protein quality control and prolong life. Cell 2014, 156, 1167-1178. [CrossRef] [PubMed]

226. Munkley, J.; Elliott, D.J. Hallmarks of glycosylation in cancer. Oncotarget 2016, 7, 35478-35489. [CrossRef] [PubMed]

227. Chiang, C.H.; Wang, C.H.; Chang, H.C.; More, S.V.; Li, W.S.; Hung, W.C. A novel sialyltransferase inhibitor AL10 suppresses invasion and metastasis of lung cancer cells by inhibiting integrin-mediated signaling. J. Cell. Physiol. 2010, 223, 492-499. [CrossRef] [PubMed]

228. Ricciardiello, F.; Votta, G.; Palorini, R.; Raccagni, I.; Brunelli, L.; Paiotta, A.; Tinelli, F.; D'Orazio, G.; Valtorta, S.; De Gioia, L.; et al. Inhibition of the Hexosamine Biosynthetic Pathway by targeting PGM3 causes breast cancer growth arrest and apoptosis. Cell Death Dis. 2018, 9, 377. [CrossRef] [PubMed]

(C) 2018 by the authors. Licensee MDPI, Basel, Switzerland. This article is an open access article distributed under the terms and conditions of the Creative Commons Attribution (CC BY) license (http://creativecommons.org/licenses/by/4.0/). 